
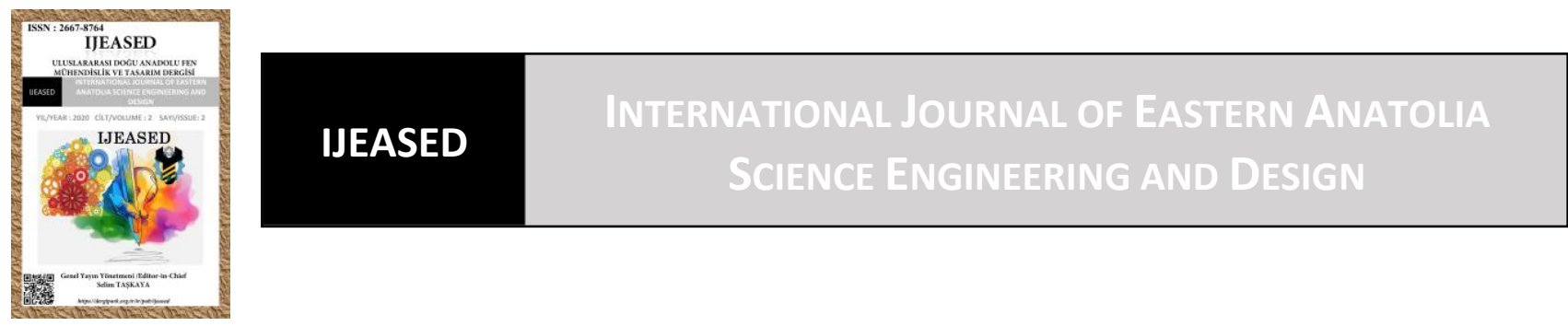

\author{
Uluslararası Doğu Anadolu Fen Mühendislik ve Tasarım Dergisi \\ ISSN: 2667-8764, 2(2), 401-433, 2020 \\ https://dergipark.org.tr/tr/pub/ijeased
}

Araştırma Makalesi / Research Article

Doi: $\underline{10.47898 / \text { ijeased.815797 }}$

\title{
Sürdürülebilirliğin Mimarlık Yüksek Lisans Programı ile Bütünleştirilmesi: Yurt Dışı ve Türkiye Örneklerinin Karşılaştırmalı Analizi
}

\author{
Fulya GÖKŞEN $^{1 a^{*}}$, İdil AYÇAM $^{1 \mathrm{~b}}$, Cansu (GÜNER) BEKLER ${ }^{1 \mathrm{c}}$
}

${ }^{1}$ Gazi Üniversitesi, Mimarlık Fakültesi, Mimarlık Bölümü, Ankara, 06000, Türkiye.

\begin{tabular}{|c|c|c|}
\hline Yazar Kimliği / Author ID (ORCID Number) & \multicolumn{2}{|c|}{ Makale Süreci / Article Process } \\
\hline $\begin{array}{l}\text { Sorumlu Yazar / Corresponding author: } \\
\text { fulyagoksen@ gmail.com } \\
\text { (i) https://orcid.org/0000-0002-9754-0956 , F. Gökşen } \\
\text { (i) https://orcid.org/0000-0001-7170-5436 , İ. Ayçam } \\
\text { iD https://orcid.org/0000-0001-7861-7404, C. Bekler }\end{array}$ & $\begin{array}{l}\text { Geliş Tarihi / Received Date : } \\
\text { Revizyon Tarihi / Revision Date : } \\
\text { Kabul Tarihi / Accepted Date : } \\
\text { Yayım Tarihi / Published Date : }\end{array}$ & $\begin{array}{l}24.10 .2020 \\
09.11 .2020 \\
29.11 .2020 \\
15.12 .2020\end{array}$ \\
\hline
\end{tabular}

Alıntı / Cite : Gökşen, F., Ayçam, İ., Bekler, C. (2020). Sürdürülebilirliğin Mimarlık Yüksek Lisans Programı ile Bütünleştirilmesi: Yurt Dişı ve Türkiye Örneklerinin Karşılaştırmalı Analizi, Uluslararası Doğu Anadolu Fen Mühendislik ve Tasarım Dergisi, 2(2), 401-433.

\begin{abstract}
Özet
Dünyanın dört bir yanındaki birçok üniversite, mimarlık programlarından mezun olacak adayları için, sürdürülebilirlik olgusunun kavramsal ve teorik açıdan yeterli düzeyde verilmesi amacıyla öğretim programlarını ve yöntemlerini, gerekli güncel bilgilerle değiştirmekte veya desteklemektedir. Tasarım ve bina teknolojilerinde sürdürülebilirlik paradigmasının gereksinimlerini karşılamak, lisans düzeyinde yaratılan farkındalığın ötesinde lisansüstü eğitimle gelişim gösterecek, yeterli mesleki bilgi ve uzmanlık sağlayacaktır. Bu alan, uygulamada halen yeterli düzeyde deneyimlenemediği için, mimari eğitim süreci ile söz konusu eksikliğin giderilmesine yönelik çalışmaların ve bilgi birikiminin verilmesini sağlayacak bir sisteme ihtiyaç olduğu açıktır. Çalışma kapsamında, farklı yaklaşımlar kullanılarak sürdürülebilirlik konularını müfredatlarına adapte etmeyi büyük oranda başarabilmiş, dünyanın farklı yerlerinde faaliyet gösteren mimarlık eğitim kurumlarının ve Türkiye'de yer alan mimarlık eğitim kurumlarının yüksek lisans düzeyindeki müfredat yapıları incelenmiştir. Hali hazırda uygulanmakta olan müfredatı, dünya örnekleri ile karşılaştırarak durum tespiti yapılmış ve ne tür güncellemeler yapılabileceği konusunda öneriler sunulmuştur. Amaç, sürdürülebilir mimarlık ve çevresel tasarım alanında uzmanlaşmak isteyen lisansüstü öğrencilerinin farkındalıklarını ve gelişim düzeylerini arttırmak için dünya örneklerinden edinilen bilgileri referans alarak, uygulanmakta olan müfredatın geliştirilmesidir.
\end{abstract}

Anahtar Kelimeler: Sürdürülebilirlik, Sürdürülebilir mimarlık, Lisansüstü mimarlık eğitimi. 


\title{
Integrating Sustainability with the Master of Architecture Program: Comparative Analysis of Foreign and Turkey Samples
}

\begin{abstract}
Many universities around the world are changing or supporting their curriculum and methods with the necessary up-todate information to ensure that candidates who aim to graduate from their architectural programs are taught the concept of sustainability at a sufficient level in regard to conceptual and theoretical. Meeting the requirements of the sustainability paradigm in design and building technologies will extend beyond the awareness created at the undergraduate level and improve with postgraduate education. Thus, a sufficient level of professional knowledge and expertise will be achieved. Since this field is still not sufficiently experienced in practice, it is clear that a system is needed to provide the works and knowledge to make up the said deficiency with the architectural education process. Scope of study, an examination of the structures of postgraduate programs of institutions located in Turkey and institutions that operate in various parts of the world who have managed to adapt the subject of sustainability to their curricula to a large degree has been carried out. By comparing the current curriculum with examples from the world, the general status was determined, and recommendations were made on what kind of updates can be made. The objective is to improve existing curricula by taking the information obtained from global examples as a reference for improving the awareness and development levels of graduate students who desire to specialize in sustainable architecture and environmental design.
\end{abstract}

Keywords: Sustainability, Sustainable architecture, Postgraduate architectural education.

\section{Giriș}

Mimarlık, yapılı çevreyi şekillendiren ve barınma, dinlenme, çalışma, eğlenme gibi temel insani ihtiyaçlarını sağlanmak üzere gerekli mekanları, işlevsel gereksinimleri ekonomik ve teknik olanaklarla bağdaştırarak estetik yaratıcılıkla tasarlayan önemli bir meslek olarak görülmektedir (Hasol, 2012; Antonara ve ark., 2013; Uzunoğlu ve Uzunoğlu, 2011). Mimarlık mesleğinin ürünü olan bir yapı var olduğu süre içinde, yakın çevresini ve tüm dünyayı birbiriyle bağlantılı insan eylemleri ve değişmesine neden olduğu doğal süreçlerle etkiler. Yapı üretiminin daha ilk evrelerinde yapı alanına yapılan müdahaleler ekolojik karakteristikleri değiştirmeye başlar. Bu nedenle yapılı çevre tasarımında, yapılı çevre ile doğal çevre arasındaki simbiyotik ilişkiyi yansıtacak köklü ve sağlam bir ekolojik anlayışın temel alınması gerekmektedir (Yeang, 2006).

Çevresel tasarım, kaynaktan üretime, kullanımdan yıkıma ve nihayetinde ekosistemler ve biyosfer içinde özümsenmeye kadar uzanan süreçte yapılı çevrenin doğal çevreyle uyumlu ve kusursuz bütünleşmesidir (Yeang, 2006). Bu kusursuz bütünleşme beşikten beşiğe (McDonough, ve Braungart, 2010) olarak tanımlanan sürdürülebilir bir döngüdür. Çevresel tasarım anlayışı kavramsal olarak incelendiğinde dolaylı veya doğrudan sürdürülebilirlik ile özdeşlik kurduğu görülmektedir.

Sürdürülebilirlik terimi toplum, ekonomi ve çevreyi içinde barındıran kapsamlı boyutlara sahiptir. Dünya ve ülke düzeyinde ortaya çıkan politik, ekonomik, sosyal gelişmeler ile bilim ve 
teknoloji alanındaki yenilikler toplumların yapısını ve yönelimlerini etkilediği gibi, eğitim kurumlarının politikalarını ve stratejilerini de etkiler. Binaların, küresel enerji tüketiminde \%36 (GlobalABC, IEA, UNE., 2019) gibi yüksek bir paydaya sahip olması ve bu tüketimin ekonomik ve çevresel boyutlarda sorunlara yol açacak sonuçlar doğurması sürdürülebilirlik kapsamında ciddi önlemlerin alınması gerektiğini göstermektedir. Alınacak önlemlerden biri küresel 1sınma, kaynakların tükenmesi ve iklim krizini içeren sürdürülebilirlik alanında mimarlık öğrencileri arasında farkındalık yaratmaktır (Altomonte, 2009; SeifHattan ve ark., 2010; Karatepe ve ark., 2012). Bu nedenle, eğitim sisteminin sürdürülebilirlik bilincini aşılamaya yönelik programlarla desteklenmesi, sürdürülebilir gelecek için büyük öneme sahiptir (Kayıhan ve Tönük, 2008).

Eğitim ortamı, profesyonel hayatın bir yansıması konumundadır ve aralarında sürekli bir ilişki söz konusudur. Mimarlık bu ilişkinin daha çok ön plana çıktı̆̆ 1 bir alandır. Bu nedenle mimarlık eğitimi günceli takip edip, yenilenerek meslekte uzmanlaşmak isteyen öğrencilere profesyonel hayatta destek olmalıdır. Günümüz koşullarında küresel gelişmeler ön planda yer almakta olup günden güne önemi artmaya devam etmektedir. Bu kapsamda sürdürülebilirlik konularının mimarlık eğitimi ile bütünleştirilmesi de daha çok önem arz etmektedir.

Dünyanın dört bir yanındaki birçok üniversite mimarlık programlarından mezun olacak mimar adayların piyasa şartlarında gelişen sürdürülebilirlik yaklaşımına karşı bilinçli ve donanımlı şekilde cevap verebilmeleri için gerekli önlemi alma çabasındadır. Bu amaçla, konu ve öğretim modülleri ek yeni bilgilerle değiştirilmekte veya desteklenmektedir. Özellikle yüksek lisans programında uzmanlık eğitimi verildiğinden dolayı bu durum daha çok önem kazanmaktadır. Tasarım ve bina teknolojilerinde sürdürülebilirlik paradigmasının gereksinimlerini karşılamak, lisans düzeyinde yaratılan farkındalığın ötesinde lisansüstü eğitimle gelişim gösterecek yeterli mesleki bilgi ve uzmanlıkla bağlantılıdır. Bu noktada sürdürülebilir mimarlık alanında lisansüstü düzeyde eğitim veren üniversitelerin öğretim programlarını ve yöntemlerini bu alanda yetkin uzmanlar yetiştirecek şekilde oluşturmalı ve küresel gelişime göre güncellemelidirler.

Yapılan literatür taramasında lisans eğitiminde gündemde olan ve tartışılan bu konunun, lisansüstü eğitiminde de üzerine düşülmesi gereken bir konu olmasına rağmen yeterince çalışmanın bulunmadığı tespit edilmiştir. Bu nedenle araştırmada, sürdürülebilirliğin mimarlık yüksek lisans eğitimi ile bütünleştirilmesi kapsamında ne durumda olduğumuzu görmek ve dünya örnekleri ile karşılaştırarak ne tür yenilikler katabileceğimizi tespit etmek adına seçilen üniversitelerdeki mimarlık yüksek lisans programlarının işleyişleri ve müfredatları incelenmiştir. Bu incelemeler ve sonrasında yapılan karşılaştırmalar referans alınarak Türkiye'deki mimarlık yüksek lisans 
programlarına sürdürülebilirlik konularının dahil edilebilmesi amacıyla müfredatın tekrar gözden geçirilmesi gerekliliği gündeme getirilmek istenmekte olup müfredatta yapılabilecek güncellemelerle ilgili öneri geliştirmek amaçlanmıştır. Veriler ilgili web sitelerinden toplanmış, sürdürülebilirlik eğitiminin mimarlıkta rolü ve mevcut durumu gözden geçirilmiş, incelenen üniversitelerde sürdürülebilirlikle bağlantılı dersleri belirlemek için kredi saatlerinin dağılımı, ders içerikleri ve uygulamaları analiz edilmiştir.

\subsection{Sürdürülebilir Mimarlık Eğitimi}

Sürdürülebilir çevre tasarımı ilke ve uygulamalarına yeni nesil mimarları ve yapılı çevrenin diğer profesyonellerini tanıtmanın bir aracı olarak yükseköğretimin rolü son derece önemlidir. UNESCO ve Uluslararası Mimarlar Birliği UIA'nın ortak olarak yayınladığı "Mimarlık Eğitim Şartı”nın sonuç bölümünde şu ifade yer almaktadır:

“Şartın, mesleki yükümlülüklerin tüm estetik, teknik ve mali yönlerinin ötesinde vurguladı̆̆ temel konu mesleğin toplumsal sorumluluğudur. Mimarın içinde bulunduğu toplumda olduğu kadar, sürdürülebilir insan yerleşimlerinde yapım kalitesinin artırlmasında da rolünün ve sorumluluğunun bilincinde olmasi gerekir.” (UNESCO ve UIA, 1996)

Dünya genelinde üniversiteler mimari programları ile sürdürülebilirliği bütünleştiren farklı yaklaşımlar uygulamıştır Bazı başarılı stratejiler, mevcut kurslara sürdürülebilirlik unsurlarını dahil eden, sürdürülebilirliğe özgü kurslar yaratan girişimler ve öğrencilerin sürdürülebilirlik bilincini geliştirmeye yönelik faaliyetler içermektedir. Tasarım stüdyoları herhangi bir mimari programın temel çalışma birimi olduğundan, yayınlanmış kapsamlı araştırmalar sürdürülebilirliği stüdyo öğretimi ile bütünleştirmek için yeni yaklaşımlar ve yöntemler önermektedir (Davis, 2010). Örneğin, Tayland'daki Naresuan Üniversitesi, stüdyo öğretimine sürdürülebilir tasarım ilkelerini dahil edebilmek amacıyla öz-farkındalık, öz değerlendirme ve özeleştirmeyi güçlendirmek amacıyla tasarım stüdyosu içinde faaliyetler geliştirmiştir (Hengrasmee ve Chansomsak, 2016). Diğer bir yaklaşım, örneğin fizik ve mimari teknolojiyi tasarım stüdyosunda, mimari uygulama ve eğitimin ayrılmaz parçalarının öncelikle estetik ve montaj odaklı bir yörüngeden tasarım düşüncesi ve bina performansı arasındaki ilişkilerin daha kapsamlı bir anlayışa dönüştürülmesi ile birleştirmektedir (Gamble ve ark., 2015). Mavromatidis (2018) çalışmasında, sürdürülebilirliği mimari eğitimle bütünleştirmek için üç eğitimsel mimari sentez modelini birleştiren bir yaklaşım uygulamıştır. Bu 
yenilikçi, didaktik yaklaşım, çok umut verici sonuçlar elde ettiği ve süreç boyunca öğrenci yaratıcılığını değiştirmekten kaçındığı bir seminer atölyesinde kullanılmıştır.

Sürdürülebilirlik ilkeleriyle uyumlu mimarlık eğitim şartlarını desteklemek ve bu şartların belirlenmesine yönelik önerilerde bulunmak amacıyla bu sürece katkıda bulunan bazı meslek dernekleri de çalışmalarını yürütmektedir. Uluslararası Mimarlar Birliği (UIA)’nın önerdiği mimari eğitim;

"Mimarlık, yapılı çevrenin ve kentsel mekanın şekillendirilmesinde yer alan kilit mesleklerden biridir. Bu nedenle, mimarları profesyonel bir yaşama hazırlayan mimari eğitim, en azından aşağıdaki bağlamlarda ve bunlarla ilgili belirli amaçlarda görülmelidir:

○ Sosyal, kültürel, politik bağlamlar

○ Profesyonel, teknolojik, endüstriyel bağlamlar

○ Dünya: yerel, küresel, ekolojik bağlamlar

○ Genel olarak bilim ve bilgi içeren akademik bağlamlar "(Riguet ve ark., 2008)

Uluslarası Mimarlık Birliği bu görüşü dahilinde sürdürülebilir yaklaşımları göz önünde bulundurduğu açıkça görülmektedir. Teknolojik ve küresel ekolojik bağlam gibi kelimeler, sürdürülebilir mimarinin ve yenilenebilir enerjilerin mimarlık eğitiminin önemli bileşenleri olduğu izlenimini vermektedir. Akademik ve meslek örgütlerinin katkılarıyla son yirmi yılda, sürdürülebilir enerji tedarik sistemleri için 21. yüzyılın ihtiyaçlarını karşılamaya çalışan mimari gibi birçok akademik branşta yenilenebilir enerji eğitimine yeni yaklaşımlar ortaya çıkmıştır (Kim, 1998). Sürdürülebilir mimari eğitiminin önemi konusunda genel bir fikir birliği olmasına rağmen, halen cevaplanmayan bazı sorular bulunmaktadır. Bu soruların bir çoğu sürdürülebilirliğin yüksek lisans eğitimiyle bütünleştirilmesi yönündedir. Mimarideki bu yeni paradigma, sadece uygulayıcılar için yöntem tasarlamada değil, aynı zamanda eğitim sistemleri üzerinde de önemli değişikliklere neden olmaktadır.

Çalışmanın sonraki bölümlerinde Yurt dışından ve Türkiye'den seçilen üniversitelerin, mimarlık bölümü yüksek lisans programlarının müfredatları incelenmiştir. Bu incelemeler sonucunda karşılaştırmalı analiz yöntemi kullanılarak Türkiye'deki yüksek lisans programlarına sürdürülebilirlik konularının entegrasyonu ve nasıl iyileştirilebileceğine yönelik önerilerde bulunulmuştur. 


\section{Materyal ve Yöntem}

Çalışmanın bu bölümünde, üniversiteler seçilirken öncelikle başarı sıralamasına, daha sonra mimarlık lisansüstü programının anabilim dalına ayrılmış olma durumuna ve müfredatlarındaki sürdürülebilirlikle ilişkili ders durumuna bakılmıştır. Özellikle yurt dışından seçilen mimarlık programlarında temel kriter, örnek teşkil edebilmesi amacıyla konu dahilindeki farklı uygulamaları bünyesinde barındırmalarıdır. Bu kapsamda, seçilen üniversitelerdeki mimarlık bölümü yüksek lisans programlarının işleyişi, ders içerikleri, kredi saatlerinin dağılımı ve uygulamaları resmi sitelerden elde edilmiştir. Müfredatta yer alan dersler sürdürülebilirlikle ilişkili düzeyine göre bağlantılı, az bağlantılı ve bağlantısız olmak üzere renklendirme yöntemi ile sınıflandırılarak tablo üzerinde bir araya getirilmiştir. Tablolardan ilişkili ders yüzdeleri çıkarılarak grafikler oluşturulmuştur. Literatürden, resmi sitelerden ve grafiklerden alınan verilerin derlenmesi ile sonuç tablosunu oluşturan parametreler belirlenmiş ve bu tablo üzerinden üniversiteler karşılaştırılmıştır.

\subsection{Yurt Dışı Mimarlık Eğitimi Yüksek Lisans Programı Müfredatlarının İncelenmesi}

Çalışma kapsamında seçilen, farklı yaklaşımlar kullanarak sürdürülebilirlik konularını müfredatlarına adapte etmeyi büyük oranda başarabilmiş dünyanın farklı yerlerinde faaliyet gösteren; Kansas Üniversitesi, Norveç Bilim ve Teknoloji Üniversitesi, Thomas Jefferson Üniversitesi, Tehran Üniversitesi Mimarlık Bölümü Yüksek Lisans Programlarının, süreci ve işleyişi hakkında kısaca bilgi verilerek, müfredatları sürdürülebilirlik konuları bağlamında incelenmiştir.

\subsubsection{Kansas Üniversitesi - Lawrence / ABD}

Mimarlık Yüksek Lisansı, Kansas Üniversitesi Mimarlık Bölümü'nde araştırmaya dayalı bir akademik programdır. Yapılı çevrenin analizinde farklı yaklaşımları araştırmak isteyen öğrenci profiline hitap eder (URL-1).

Kansas Üniversitesi Mimarlık yüksek lisans programı (Tablo 1), 3 akademik yı1, 2 mimari tasarım stüdyosu ve 118 kredi saatini karşılayan bölüm derslerinden başarılı olunması şeklinde kurgulanmıştır. İkinci akademik yıl, kapsamlı stüdyo dönem projesi deneyimi olarak profesyonel gelişimi desteklemektedir. Üçüncü ve son yıl, öğrencilerin belli bir alanda uzmanlaşma sürecini 
içerir. Öğrenci çalışmak istediği alanı seçer ve bu programdan mezun olduktan sonra çalıştıkları alanda uzmanlık geliştirmesini sağlar (URL-2).

Yüksek lisans programının son yılında öğrenciler, uygulamalı proje tasarım stüdyosu olan Studio 804'de y1l boyunca kapsamlı eğitim görmektedir. Öğrenciler inşa edecekleri yapının detay çizimlerini geliştirerek, yapı malzemelerinin sitede nasıl bir araya geldiklerine dair fikir edinirler. Bina kod yetkilileri, profesyonel mühendislik danışmanları, malzeme tedarikçileri ile doğrudan çalışarak ve birbirleriyle işbirliği yaparak, sadece mezun olduktan sonra karşılaşacakları gerçek hayat deneyimini eğitim sürecinde kazanırlar. Studio 804 uygulamalı tasarım stüdyosunun başladığından günümüze kadar ki süreçte Kansas halkına; Greensburg 547 Art Center (2008), Kansas Üniversitesi Batı Kampüsü Tasarım Araştırmaları Merkezi (2011), Johnson County Community College (2012), Hill Engineering Research and Development Center (2013) ve iki düşük maliyetli ev prototipi kazandırmıştır (Şekil 1). Bu binaların tümü, ABD Yeşil Bina Konseyi'nden LEED Platinum sertifikalarına sahiptir (URL-3).
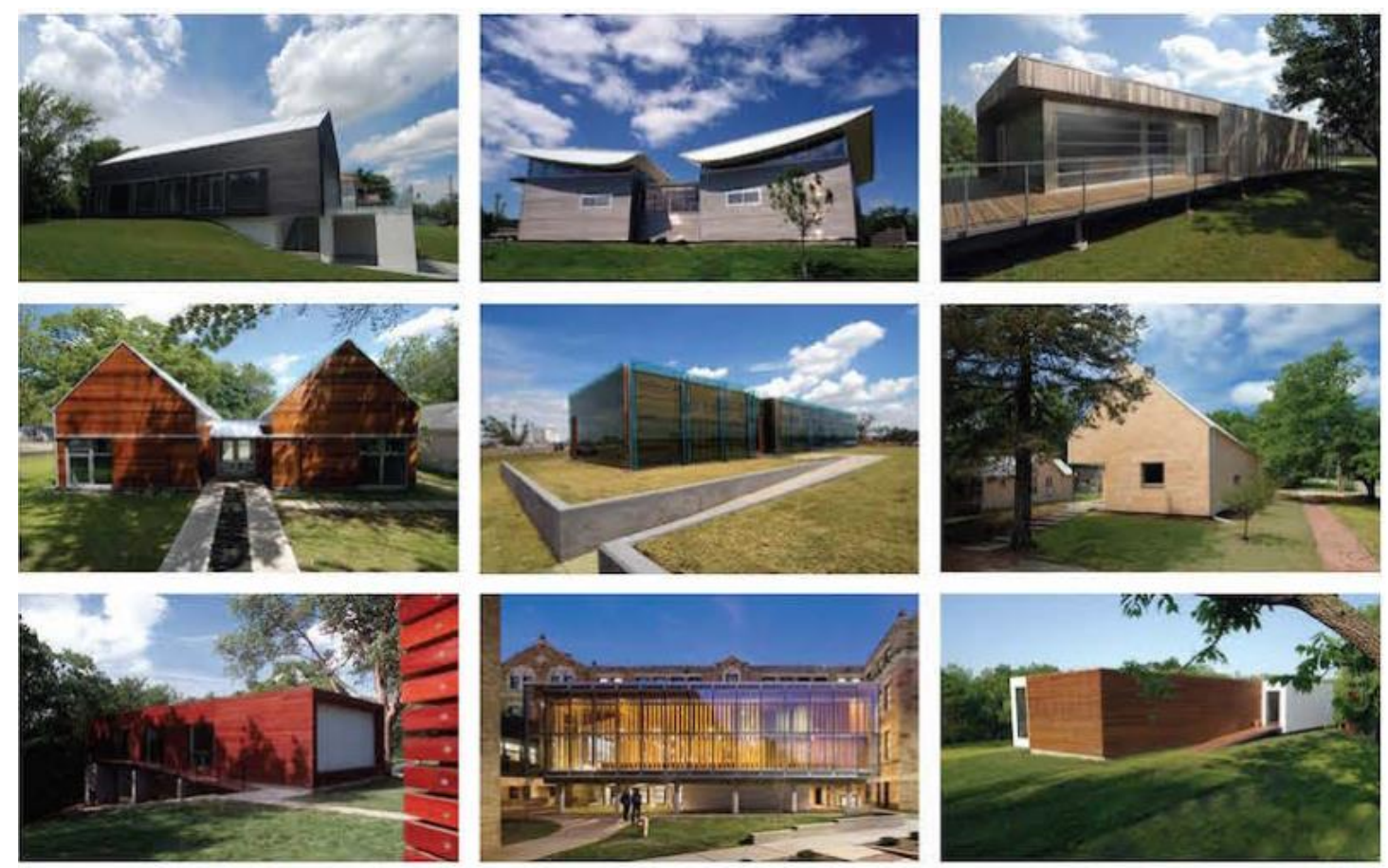

Şekil 1. Kansas Üniversitesi Stdio 804 projeleri (URL-3)

Yüksek Lisans programın genel kurgusu bu şekilde olmasına rağmen öğrencinin lisans düzeyinde aldıkları eğitime göre de farklılık gösterebilir (URL-2):

- Tasarım odaklı olmayan disiplinlerden lisans derecesine sahip mimarlık alanında lisans derecesi olmayan öğrenciler, yaz oturumunda başlayan müfredatın ilk yılına girerler. 
Gökşen, F., Ayçam, I., Bekler, C., Uluslararası Doğu Anadolu Fen Mühendislik ve Tasarım Dergisi / International Journal of Eastern Anatolia Science Engineering and Design (IJEASED)

(2020) 2(2):401-433

Müfredatın ilk yılı; 2 akademik dönem ve 2 yaz dönemidir. Gerekli toplam kredi süresi öğrencinin lisans da aldığı derslere bağlı olarak 110-116 kredi saatidir.

- Tasarım disiplini alanında lisans derecesine sahip olup Mimarlık alanında lisans derecesine sahip olmayan öğrencilerin ders çalışmalarına ilk yılın güz dönemi başlamaktadır. Mezuniyet için gerekli toplam kredi saatinin 100 kredi saati olması gerekmektedir.

○ Mimarlık alanında akredite olmayan lisans derecesine sahip öğrencilerin eğitime programın ikinci yılında başlamaktadır. Bu uygulama 4+2 seçeneği olarak isimlendirilir. $\mathrm{Bu}$ öğrencilerin normal olarak dört stüdyo (sentez deneyimleri), yurtdışında yaz çalışması, sayı ve içerikleri duruma göre belirlenen mimari destek kurslarını tamamlamaları istenir. Mezuniyet için gerekli olan toplam kredi süresi, öğrencinin lisans derecesinde aldığı derslere bağlıdır ve oldukça değişkendir, ancak yaklaşık 70 kredi saat olması istenmektedir

○ Akredite Mimarlık lisans derecesine sahip öğrenciler, bir yaz döneminde ve müfredatın son yılında yurtdışında eğitim gerektiren üç dönemlik bir programa girerler. Mezuniyet için gerekli toplam kredi süresi, öğrencinin lisans döneminde aldığı derslere bağlı olarak değişkenlik göstermesiyle en az 36 kredi saat gereklidir.

Tablo 1. KU Mimarlık Yüksek lisans programı dersleri (URL-4)

\begin{tabular}{|c|c|c|c|c|c|}
\hline \multicolumn{2}{|c|}{ Dönem } & \multirow{2}{*}{ Dersin Kodu } & Dersin Ad 1 & \multicolumn{2}{|c|}{$\begin{array}{cc}\text { Kredi Durum } \\
\text { Saati }\end{array}$} \\
\hline \multirow{14}{*}{$\Xi$} & \multirow{3}{*}{ : } & & Strüktür I & 3 & Zorunlu \\
\hline & & ARCH 530 & Çevre Sistemleri I & 3 & Zorunlu \\
\hline & & ARCH 626 & Yap1 Teknolojisi I: Yapı Sistemleri ve Montajları & 3 & Zorunlu \\
\hline & \multirow{3}{*}{$\underset{\tilde{\Xi}}{\tilde{\Xi}}$} & ARCH 531 & Çevre Sistemleri II & 3 & Zorunlu \\
\hline & & ARCH 624 & Strüktür II & 3 & Zorunlu \\
\hline & & $\mathrm{ARCH}$ & Profesyonel Zenginleştirme Seçmeli & 3 & Seçmeli \\
\hline & \multirow{5}{*}{ 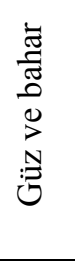 } & ARCH 508 & Malzeme ve Tektonik & 6 & Zorunlu \\
\hline & & ARCH 509 & Bina Tasarımı & 6 & Zorunlu \\
\hline & & ARCH 510 & Mimari Detaylandırma & 3 & Zorunlu \\
\hline & & ARCH 630 & Mimarlık Kuramı & 3 & Zorunlu \\
\hline & & \multicolumn{4}{|c|}{$\begin{array}{l}\text { *Not: Hem güz hem bahar döneminde geçerli olmak üzere; ARCH } 508 \text { veya 509, ARCH } 510 \text { veya } 630 \\
\text { seçilmelidir }\end{array}$} \\
\hline & \multirow{3}{*}{ స్ర } & ARCH 501 & Hızlandırılmış Tasarım & 6 & Zorunlu \\
\hline & & ARCH 502 & Hızlandırılmış Tasarım II & 6 & Zorunlu \\
\hline & & ARCH 605 & Saha ve Doğal Çevre Sistemlerinin Görselleştirilmesi & 3 & Zorunlu \\
\hline \multirow{4}{*}{ 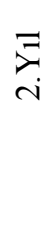 } & \multirow{4}{*}{ : } & ARCH 608 & Kentsel Konut & 6 & Zorunlu \\
\hline & & ARCH 540 & $\begin{array}{l}\text { Küresel Mimarlık Tarihi I: Sanayi Devriminin Kökenleri (MÖ } \\
3500 \text { - MS 1700). } 3 \text { Saat }\end{array}$ & 3 & Zorunlu \\
\hline & & ARCH 658 & Programlama ve Tasarım Öncesi Konular & & Zorunlu \\
\hline & & $\mathrm{ARCH}$ & Profesyonel Zenginleştirme Seçmeli & 3 & Seçmeli \\
\hline
\end{tabular}




\begin{tabular}{|c|c|c|c|c|c|}
\hline & \multirow{4}{*}{ 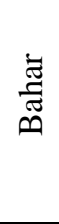 } & ARCH 609 & Bütünleşik Tasarım & 6 & Zorunlu \\
\hline & & ARCH 541 & $\begin{array}{l}\text { Küresel Mimarlık Tarihi II: Sanayi Devriminden Günümüze } \\
\text { (1700 CE-Hali) }\end{array}$ & 3 & Zorunlu \\
\hline & & ARCH 552 & Mesleki Uygulamada Etik ve Liderlik & 3 & Zorunlu \\
\hline & & ARCH 610 & Bütünleşik Tasarım Belgeleri & 3 & Zorunlu \\
\hline & \multirow{2}{*}{ 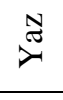 } & & \multirow[b]{2}{*}{ Yurt Dışı Mimarlık Çalışması } & & \\
\hline & & ARCH 690 & & 6 & Zorunlu \\
\hline \multirow{5}{*}{$\vec{\nexists}$} & \multirow{2}{*}{ 洽 } & ARCH 800 & Mimarlıkta Özel Konular & 6 & Zorunlu \\
\hline & & $\mathrm{ARCH}$ & 3 Adet Profesyonel Zenginleştirme Seçmeli & 3 & Seçmeli \\
\hline & \multirow{3}{*}{ 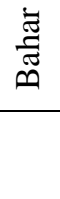 } & ARCH 800 & Mimarlıkta Özel Konular II & 6 & Zorunlu \\
\hline & & $\mathrm{ARCH}$ & 3 Adet Profesyonel Zenginleştirme Seçmeli & 3 & Seçmeli \\
\hline & & \multicolumn{2}{|c|}{$\begin{array}{c}\text { Sürdürülebilirlikle } \\
\text { Bağlantılı }\end{array}$} & $\begin{array}{l}\text { ilirlikle } \\
\text { tisiz }\end{array}$ & \\
\hline
\end{tabular}

\subsubsection{Norveç Bilim ve Teknoloji Üniversitesi (NTNU) - Trondheim/Norveç}

NTNU'daki Sürdürülebilir Mimari Yüksek Lisans programı, binaların yaşam döngüsü boyunca çevresel etkilerini azaltmak için çözümlerin analizi ve uygulanması konusunda mimarları eğitmeyi amaçlamaktadır. Programdaki öğrenciler, hem bilimsel araştırma çalışmalarının geliştirilmesi hem de sıfır emisyonlu yapılı çevreyi hedefleyen mimari tasarım projeleri geliştirme konusunda eğitilmektedir. Şekil.2'de örnek bir proje tasarımı ve uygulaması yer almaktadır. (URL5; URL-6)
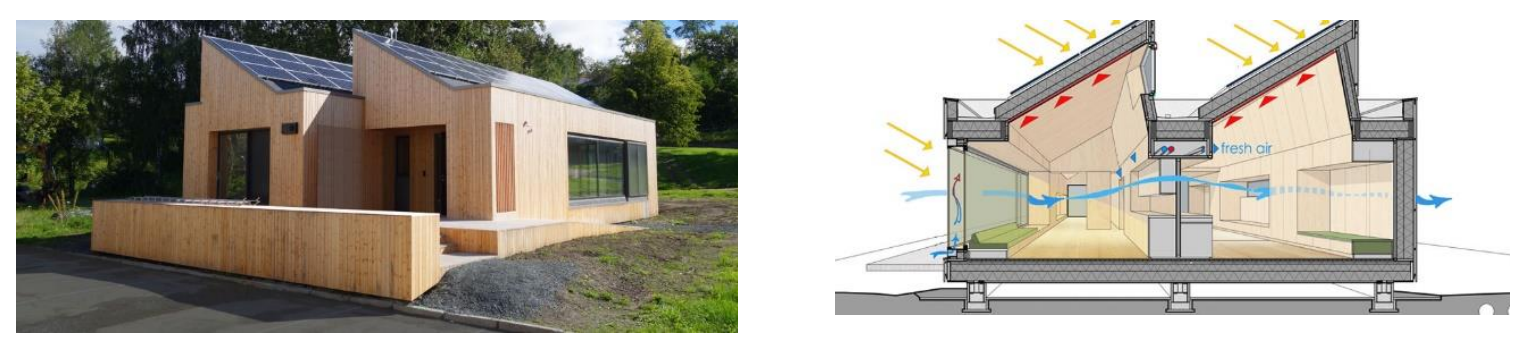

Şekil 2. NTNU sürdürülebilir mimari yüksek lisans programı örnek proje çalışması

Program (Tablo 2), 2 akademik yıl sürer ve 120 AKTS'lik bir ders yükü içermektedir. Müfredat oluşturulurken, yapılı çevrenin çevresel etkileri ile ilgili; çevresel performans, çevresel etki ve bütünleşik enerji tasarım süreçleri olmak üzere tez dönemi hariç her dönem için bir başlık altında ders programı oluşturulmuştur. Her dönem bir teori ve mimari tasarım dersi içermektedir. Dersler, her dönem hem stüdyo hem laboratuvarlarda bir bütün olarak işlenmektedir. Teori ve proje derslerinin her birinde, tasarımın çevresiyle ve kullanıcılarıyla bütünlüğünü sağlamak için bütüleşik 
Gökşen, F., Ayçam, I., Bekler, C., Uluslararası Doğu Anadolu Fen Mühendislik ve Tasarım Dergisi / International Journal of Eastern Anatolia Science Engineering and Design (IJEASED)

(2020) 2(2):401-433

tasarım stratejileri ön planda tutulmaktadır. Program boyunca öğrencilerin, bütünleşik tasarım yöntemlerini özümseyip uygulayabilmeleri için disiplinler arası işbirliği konusunda sürekli olarak eğitimler verilmektedir (Tablo 2). (URL-5; URL-6)

○ I Ilk dönem, iklim analizleri ve binaların çevresel performansının optimizasyonu üzerine odaklanılmaktadır.

○ İkinci dönem, malzemelerin çevresel etkileri ve yaşam döngüsü analizleri ile ilgili konuları ele alınmaktadır. Bu kapsamda genellikle mevcut binaların dönüşümü üzerinde çalışılmıştır.

○ Üçüncü dönem, alternatif yenilenebilir enerji sistemlerinin entegrasyonu ile binanın çevresel performansını optimize eden bütünleşik tasarım süreçlerinin geliştirilmesi konusunda eğitim verilmektedir. Bu dönemde öğrenciler ZEN araştırma merkezi ile bağlantılı olarak çalışmakta olup yüksek lisans tezinin geliştirilmesi için ön çalışmaları bu aşamada oluşturmaktadırlar.

○ Dördüncü dönem ise, 30 AKTS olan yüksek lisans tezine ayırılmıştır.

Tablo 2. NTNU Mimarlık Yüksek lisans programı dersleri (URL-5; URL-6)

\begin{tabular}{|c|c|c|c|c|c|}
\hline & & $\begin{array}{l}\text { Dersin } \\
\text { Kodu }\end{array}$ & Dersin Adı & AKTS & Durum \\
\hline \multirow{8}{*}{$\underset{7}{\beth}$} & \multirow{5}{*}{ : } & Çevresel Pc & mans & & \\
\hline & & AAR4532 & İklim ve Yapılı Form Tasarım Projesi & 15 & Zorunlu \\
\hline & & AAR4832 & İklim ve Yapılı Form & 7.5 & Zorunlu \\
\hline & & AAR4833 & Sürdürülebilir Mimarlıkta Kavramlar ve Stratejiler & 7.5 & Zorunlu \\
\hline & & HMS0004 & $\begin{array}{l}\text { AD Fakültesinde Öğrenciler için Atölye Eğitimi ile Sağlık, } \\
\text { Emniyet ve Çevre (SEÇ) Kursu }\end{array}$ & 0 & Zorunlu \\
\hline & \multirow{3}{*}{ 䒿 } & Çevresel Et & & & \\
\hline & & AAR4546 & Tasarım Sürücüleri Olarak Emisyonlar - Tasarım & 15 & Zorunlu \\
\hline & & AAR4817 & Tasarım Sürücüleri Olarak Emisyonlar - Teori & 7.5 & Zorunlu \\
\hline \multirow{7}{*}{$\begin{array}{l}\nexists \\
i\end{array}$} & \multirow{5}{*}{ : : } & Bütünleşik & rji Tasarım Süreçleri & & \\
\hline & & AAR4616 & Bütünleşik Enerji Tasarım Projesi & 15 & Zorunlu \\
\hline & & AAR4926 & Bütüneşik Enerji Tasarımı - Teori & 7.5 & Zorunlu \\
\hline & & AAR4850 & Işık ve Aydınlatma & 7.5 & Seçmeli \\
\hline & & TEP4235 & Binalarda Enerji Yönetimi & 7.5 & Seçmeli \\
\hline & \multirow{2}{*}{ 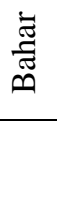 } & AAR4993 & Yüksek Lisans Sürdürülebilir Mimarlıkta Tez & 30 & Zorunlu \\
\hline & & $\begin{array}{r}\text { Sürdürüleb } \\
\text { Bağlaı }\end{array}$ & $\begin{array}{l}\text { Sürdürülebilirlikle } \\
\text { Az Bağlantılı }\end{array}$ & $\begin{array}{l}\text { ilirlikle } \\
\text { tisiz }\end{array}$ & \\
\hline
\end{tabular}




\subsubsection{Thomas Jefferson Üniversitesi - Philadelphia / USA}

Thomas Jefferson Üniversitesi, gelişmiş cephe teknolojisi ve yüksek performanslı binalar, kentsel tasarım, yapı yönetimi, iç mekan tasarımı, tarihi yapılar, gayrimenkul geliştirme ve sürdürülebilir mimarlık gibi mimarlığın bir çok alanında lisansüstü eğitim vermektedir (URL-7).

Bu çalışma kapsamında ele alınacak olan "Sürdürülebilir Mimarlık” lisansüstü programı ile öğrencilerin, topluma daha iyi hizmet verebilmek, sürdürülebilir tasarımda lider olmak için pazar odaklı çözümler geliştirmek üzere problem çözme becerilerini geliştirmeyi amaçlamaktadır. Bütünleşik tasarım modeline dayanan program, tasarım sürecinin erken aşamalarında öğrencileri uzmanlara, tasarım seçeneklerine ve gerçek dünya kısıtlamalarına tanıtması öğrencilerin hali hazırdaki işleyişi yakından görebilmeleri açısından avantaj sağlamaktadır (URL-8; URL-9).
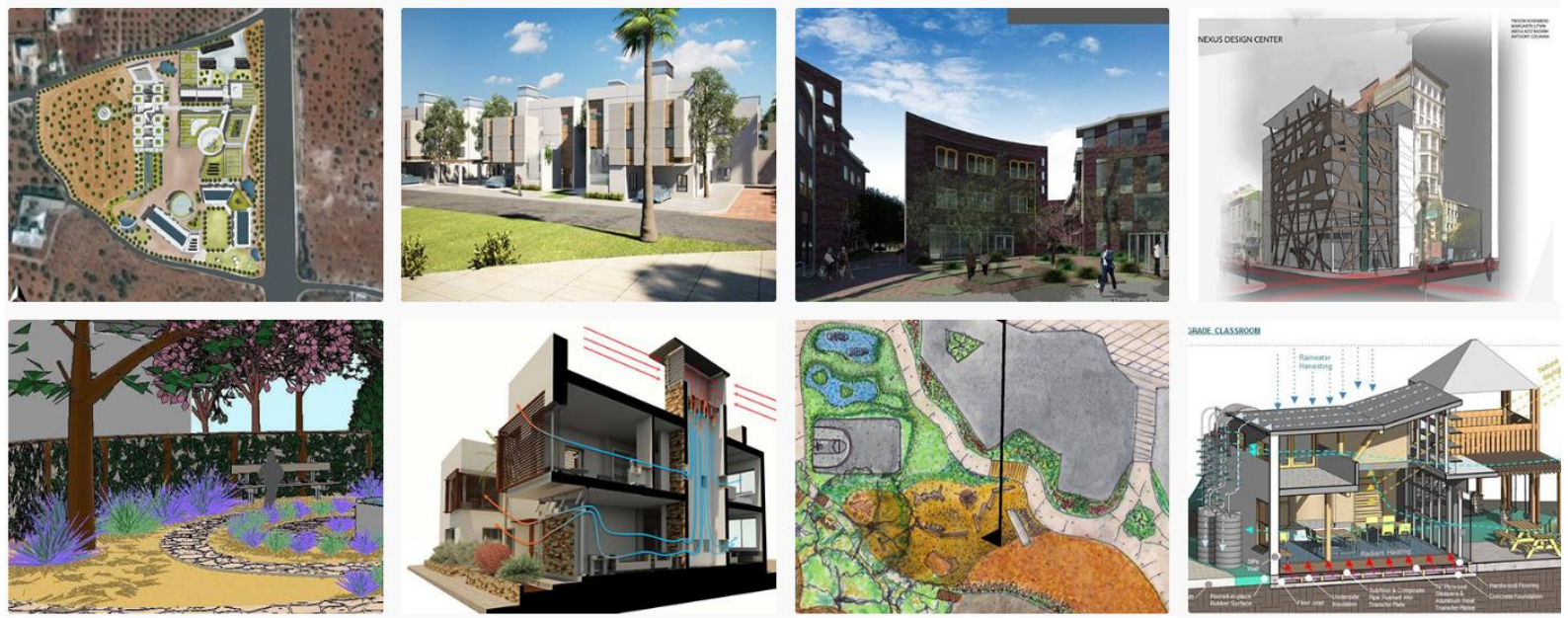

Şekil 3. Thomas Jefferson Üniversitesi sürdürülebilir mimari yüksek lisans programı örnek proje çalışması

(URL-10)

Lisansüstü eğitimi dışında 6-12 aylık sertifika eğitimleri ile öğrenciler programın gerektirdiği zorunlu ders kredisini tamamlayarak katıldığı programın sertifikasını alabiliyor, alanlarında uzman olarak çalışma imkanı bulmaktadır. Ayrıca öğrenciler sertifika kursları yoluyla kazanılan kredileri yüksek lisans programına başvurup kabul edilmeleri halinde saydırıp lisansüstü eğitimini tamamlama imkanı da bulabilmektedir (URL-11).

Sürdürülebilir Mimarlık lisansüstü eğitimi (Tablo 3) 2 akademik y1l olup 33 kredilik ders yükü içermektedir. Öğrenciler, "Sürdürülebilir Tasarım” programı bünyesindeki derslerden 12 ders kredisi, başka programlardan 12 ders kredisi ve tezden veya dönem projesiyle beraber bir seçmeli 
Gökşen, F., Ayçam, I., Bekler, C., Uluslararası Doğu Anadolu Fen Mühendislik ve Tasarım Dergisi / International Journal of Eastern Anatolia Science Engineering and Design (IJEASED)

(2020) 2(2):401-433

dersten 9 kredi ile istenilen ders yükünü karşılayabilmekte ve kendi müfredatını kendisi tasarlayabilmektedir (Şekil 4).

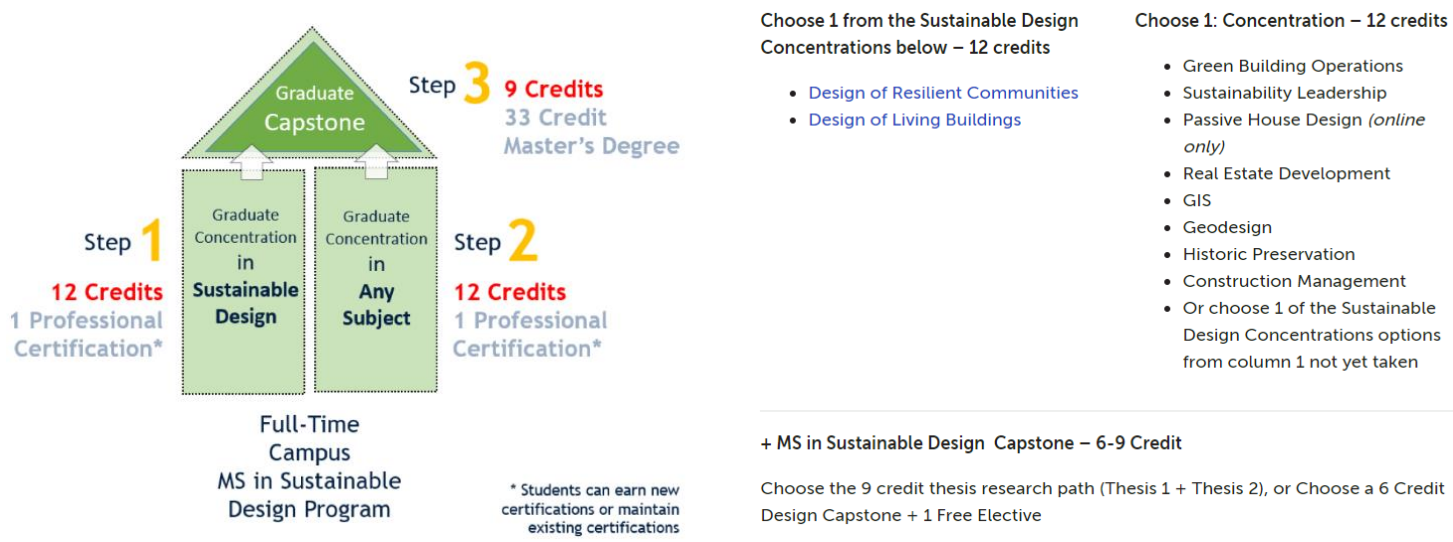

Şekil 4. Sürdürülebilir Tasarım Lisansüstü Programı ders seçim diyagramı (URL-12)

Tablo 3. Thomas Jefferson Üniversitesi sürdürülebilir mimari yüksek lisans programı dersleri

\begin{tabular}{|c|c|c|c|c|}
\hline \multicolumn{2}{|c|}{ Dönem } & Dersin Adr & $\begin{array}{l}\text { AKTS } \\
\text { (kredi) }\end{array}$ & Durum \\
\hline \multirow{12}{*}{ 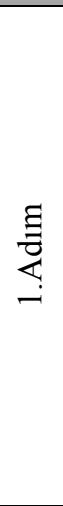 } & \multirow{6}{*}{ : } & Yaşayan Bina Tasarımı & & \\
\hline & & Yaşayan Binalar için Sürdürülebilir Sistemler & 5 & Seçmeli \\
\hline & & Yaşayan Bina Tasarım Stüdyosu & 10 & Seçmeli \\
\hline & & Esnek Toplulukların Tasarımı & & \\
\hline & & Sürdürülebilir Tasarım Kriterleri & 7.5 & Seçmeli \\
\hline & & Uyarlanabilir ve Esnek Tasarım & 7.5 & Seçmeli \\
\hline & \multirow{6}{*}{ 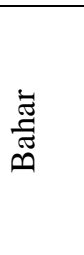 } & Yaşayan Bina Tasarımı & & \\
\hline & & Sürdürülebilir Tasarım İlkeleri & 7.5 & Seçmeli \\
\hline & & Yaşayan Bina Temel & 7.5 & Seçmeli \\
\hline & & Esnek Toplulukların Tasarımı & & \\
\hline & & Esnek Peyzaj için Sürdürülebilir Sistemler & 5 & Seçmeli \\
\hline & & Esnek Topluluklar Tasarım Stüdyosu & 10 & Seçmeli \\
\hline \multirow{19}{*}{ 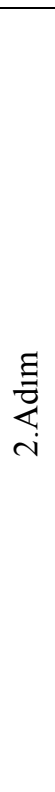 } & \multirow{17}{*}{ : } & Sürdürülebilirlik Liderliği & & \\
\hline & & Sürdürülebilir Tasarım İlkeleri & 7.5 & Seçmeli \\
\hline & & Çevresel Etki Analizi & 7.5 & Seçmeli \\
\hline & & Yeşil Bina Operasyonları (Başlıkta listelenen derslerden 1'i seçilecek) & & \\
\hline & & Sürdürülebilir Tasarım İlkeleri & 7.5 & Seçmeli \\
\hline & & Uyarlanabilir ve Esnek Tasarım Temelleri & 7.5 & Seçmeli \\
\hline & & Yeșil Binalar için Sürdürülebilir Sistemler & 7.5 & Seçmeli \\
\hline & & Yaşam Döngüsü ve Yeşil Malzemeler & 7.5 & Seçmeli \\
\hline & & Sürdürülebilir Tasarım için BIM & 7.5 & Seçmeli \\
\hline & & Sürdürülebilirlik Uygulaması & 7.5 & Seçmeli \\
\hline & & Refah İçin Ortamlar & 7.5 & Seçmeli \\
\hline & & Ekoloji ve Üretim & 7.5 & Seçmeli \\
\hline & & Örnek Olay: Sürdürülebilir Uygun Fiyatlı Konut & 7.5 & Seçmeli \\
\hline & & İnşaat Çevre Yönetimi & 7.5 & Seçmeli \\
\hline & & Pasif Ev Tasarımı & & \\
\hline & & Sürdürülebilir Tasarım Kriterleri & 7.5 & Seçmeli \\
\hline & & Pasif Ev Konusuna Giriş & 7.5 & Seçmeli \\
\hline & \multirow{2}{*}{$\underset{\tilde{E}}{\tilde{E}}-$} & Sürdürülebilirlik Liderliği & & \\
\hline & & Sürdürülebilir Kuruluşlar için Modeller ve Metrikler & 7.5 & Seçmeli \\
\hline
\end{tabular}




\begin{tabular}{|c|c|c|c|c|}
\hline \multicolumn{5}{|c|}{ Yeşil Bina Operasyonları (Başlıkta listelenen derslerden 2'si seçilecek) } \\
\hline & & Sürdürülebilir Tasarım İlkeleri & 7.5 & Seçmeli \\
\hline & & Uyarlanabilir ve Dayanıklı Tasarım Temelleri & 7.5 & Seçmeli \\
\hline & & Yeşil Binalar için Sürdürülebilir Sistemler & 7.5 & Seçmeli \\
\hline & & Yaşam Döngüsü ve Yeșil Malzemeler & 7.5 & Seçmeli \\
\hline & & Sürdürülebilir Tasarım için BIM & 7.5 & Seçmeli \\
\hline & & Sürdürülebilirlik Uygulaması & 7.5 & Seçmeli \\
\hline & & Refah İçin Ortamlar & 7.5 & Seçmeli \\
\hline & & Ekoloji ve Üretim & 7.5 & Seçmeli \\
\hline & & Örnek Olay: Sürdürülebilir Uygun Fiyatlı Konut & 7.5 & Seçmeli \\
\hline & & İnşaat Çevre Yönetimi & 7.5 & Seçmeli \\
\hline & & Pasif Ev Tasarımı & & \\
\hline & & Pasif Ev Sistemleri & 5 & Seçmeli \\
\hline & & Pasif Ev Tasarım Stüdyosu & 10 & Seçmeli \\
\hline & $\dot{\theta}$ & Sürdürülebilirlik Liderliği & & \\
\hline & $\underset{\nearrow}{\overparen{\nearrow}}$ & Sürdürülebilirlik Savunuculuk ve Değişim Yönetimi & 7.5 & Seçmeli \\
\hline \multirow{5}{*}{ 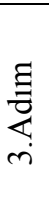 } & \multirow{5}{*}{ 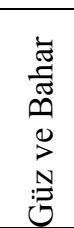 } & Seçenek 1 & & \\
\hline & & Tez Çalışması & 22.5 & Seçmeli \\
\hline & & Seçenek 2 & & \\
\hline & & Dönem Projesi & 15 & Seçmeli \\
\hline & & Seçmeli ders & & Seçmeli \\
\hline & & $\begin{array}{c}\text { Sürdürülebilirlikle } \\
\text { Bağlantılı }\end{array}$ & $\begin{array}{l}\text { Sürdürülebilirlikle } \\
\text { Bağlantısız }\end{array}$ & \\
\hline
\end{tabular}

\subsubsection{Tehran Üniversitesi - Kish Adası/ İran.}

Tehran Üniversitesi Mimarlık Bölümü sürdürülebilir ve enerji konuları alanındaki lisansüstü eğitimini Mimarlık ve Enerji ana bilim dalı altında vermektedir. Mimarlık ve Enerji lisansüstü programı; mevcut ve gelecek nesil mimarların, yapı alanındaki uzmanların karşılaştığı küresel çevre ve enerji sorunu, çevresel tasarım ilkeleri ve bunların mimari pratiğe etkili bir şekilde uygulanması konusunda daha derin bir anlayış gerektirmektedir. Öğrenciler aldıkları eğitimle mimari tasarımın çeşitli aşamaları ile ilgili çevresel tasarım yöntemlerini öğrenecek, mevcut binaları değerlendirebilecek, bütünleşik biyoklimatik tasarım ve kullanıcı odaklı yaklaşımı izleyerek yenilerini tasarlayabilecek bilgi birikimine erişeceklerdir (URL-13).

Program (Tablo 4), ders dönemi 4 yarıyıl, tez dönemi 2 yarıyıl olacak şekilde toplam süresi 3 akademik yıl olarak kurgulanmıştır. Öğrencilerin yüksek lisans eğitimlerini tamamlamaları için 80 AKTS'yi tamamlamaları gerekmektedir (URL-14). 
Gökşen, F., Ayçam, I., Bekler, C., Uluslararası Doğu Anadolu Fen Mühendislik ve Tasarım Dergisi / International Journal of Eastern Anatolia Science Engineering and Design (IJEASED)

(2020) 2(2):401-433

Tablo 4.Tehran Üniversitesi Mimarlık ve Enerji yüksek lisans programı dersleri (Taleghani ve ark., 2011)

\begin{tabular}{|c|c|c|c|c|}
\hline \multicolumn{2}{|c|}{ Dönem } & Dersin Adl & $\begin{array}{l}\text { AKTS } \\
\text { (kredi) }\end{array}$ & Durum \\
\hline \multirow{8}{*}{$\nexists$} & \multirow{4}{*}{ : } & Mimarlık ve Kentleşmede Enerji Yönetimi & 5 & Seçmeli \\
\hline & & Yer Koşulları Kontrolü & 5 & Seçmeli \\
\hline & & Bina ve yazılım kullanımında enerji simülasyonu & 5 & Seçmeli \\
\hline & & Seminer & 7.5 & Zorunlu \\
\hline & \multirow{4}{*}{ 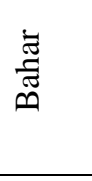 } & İklim ve Vernaküler Mimarri & 5 & Seçmeli \\
\hline & & Aktif Pasif Güneş Sistemleri Detayları & 5 & Seçmeli \\
\hline & & Araştırma Yöntemleri & 5 & Seçmeli \\
\hline & & Mimari Tasarım ve Enerji I & 7.5 & Zorunlu \\
\hline \multirow{6}{*}{$\begin{array}{l}\bar{\lambda} \\
\dot{i}\end{array}$} & \multirow{3}{*}{ : } & Ekolojik Tasarım Temeli & 5 & Seçmeli \\
\hline & & Yapı Fiziği & 5 & Seçmeli \\
\hline & & Mimari Tasarım ve Enerji II & 7.5 & Zorunlu \\
\hline & \multirow{3}{*}{ 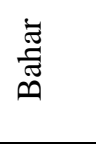 } & Kentsel Tasarım ve Enerji & 10 & Zorunlu \\
\hline & & Bina İnşaat Adımları & 5 & Seçmeli \\
\hline & & Planlama ve Tasarım Yöntemleri & 5 & Seçmeli \\
\hline \multirow{2}{*}{$\bar{z}$} & 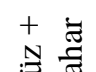 & Tez Çalışması I & 15 & Zorunlu \\
\hline & & $\begin{array}{l}\text { Sürdürülebilirlikle } \\
\text { Bağlantılı }\end{array}$ & $\begin{array}{l}\text { ilirlikle } \\
\text { tisız }\end{array}$ & \\
\hline
\end{tabular}

\subsubsection{Müfredat Analizi Sonucu Ders Durumları}

Kansas Üniversitesi, Mimarlık yüksek lisans programı, özelleşmiş bir anabilim dalı olmamasına rağmen, bağlantılı ve bağlantısız ders sayısı eşit olup \%48 oranında sürdürülebilirlikle bağlantılı, \%4 oranında sürdürülebilirlikle az bağlantılı ve \%48 oranında sürdürülebilirlikle bağlantılı olmayan derslerden oluşmaktadır (Şekil 5).

Norveç Bilim ve Teknoloji Üniversitesi, Sürdürülebilir Mimari Yüksek Lisans Programı Ana Bilim Dalı olarak sürdürülebilir mimari üzerine özelleşmiş olmasında dolayı, \%67 oranında sürdürülebilirlikle bağlantılı, \%20 oranında sürdürülebilirlikle az bağlantılı derslerlerden oluşmakta olup bağlantılı olmayan ders bulunmamaktadır. (Şekil 5).

Thomas Jefferson Üniversitesi, Sürdürülebilir Mimarlık Yüksek Lisans programı, Ana Bilim Dalı olarak sürdürülebilir mimari üzerine özelleşmiş olmasında dolayı \%98 oranında sürdürülebilirlikle bağlantılı, \%8 oranında sürdürülebilirlikle az bağlantılı ve $\% 3$ oranında sürdürülebilirlikle bağlantılı olmayan derslerden oluşmaktadır (Şekil 5).

Tehran Üniversitesi, Mimarlık ve Enerji lisansüstü programı, Ana Bilim Dalı olarak sürdürülebilir mimari üzerine özelleşmiş olmasından dolayı $\% 67$ oranında sürdürülebilirlikle 
bağlantılı, \%20 oranında sürdürülebilirlikle az bağlantılı ve \%13 oranında sürdürülebilirlikle bağlantılı olmayan derslerden oluşmaktadır (Şekil 5).

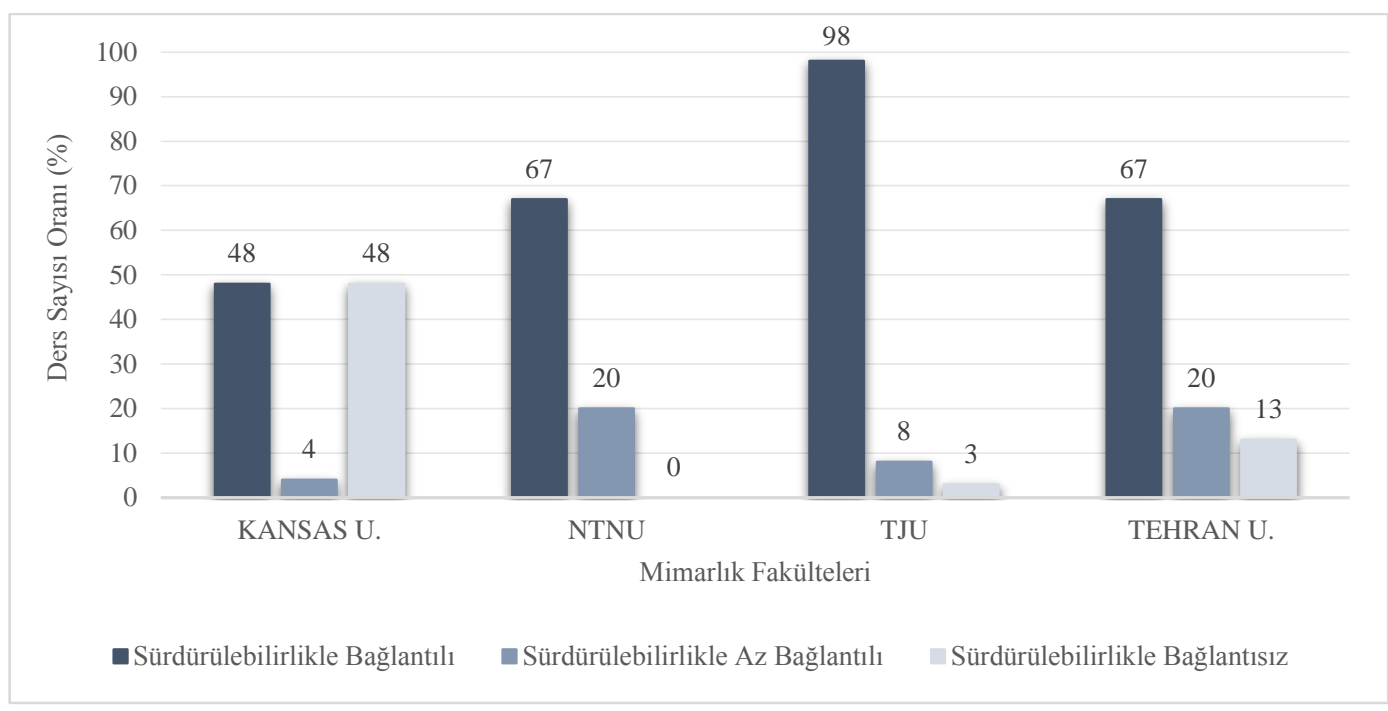

Şekil 5. Yurt Dışından Seçilen Üniversitelerin, Mimarlık Yüksek Lisan Programı Müfredat Analizleri Sonucu Sürdürülebilirlikle Bağlantılı Ders Durumları

\subsection{Türkiye Mimarlık Eğitimi Yüksek Lisans Programı Müfredatlarının İncelenmesi}

Bu bölümde Türkiye'den seçilen; İstanbul Teknik Üniversitesi, Yıldız Teknik Üniversitesi, İzmir Yüksek Teknoloji Üniversitesi, Gazi Üniversitesi, Gebze Teknik Üniversitesi Mimarlık Bölümü Yüksek Lisans Programlarının, süreci ve işleyişi hakkında kısaca bilgi verilerek, müfredatları sürdürülebilirlik konuları bağlamında incelenmiştir.

\subsection{1. İstanbul Teknik Üniversitesi - İstanbul}

İstanbul Teknik Üniversitesi Mimarlık Ana Bilim Dalı altında; Mimarlık (Tezsiz), Mimari Tasarım, Çevre Kontrolü ve Yapı Teknolojisi, Yapı Bilgisi, Mimarlık Tarihi, Restorasyon, Proje ve Yapım Yönetimi gibi yüksek lisans programları bulunmaktadır.

Çalışma kapsamında ele alınacak olan Çevre Kontrolü ve Yapı Teknolojisi Yüksek Lisans Program'ı ile yeni kuşaklara yaşanabilir bir çevre bırakmak için, daha az doğal kaynak ve daha az enerji tüketilmesi gerektiği bilincine sahip mimarlar yetiştirmeyi hedeflemektedir. (URL-15)

Bu kapsamda öğrencilere; 
○ Sağlıklı ve konforlu olduğu kadar enerji ve çevre duyarlı, sürdürülebilir bir yapma çevre tasarımı yapma,

○ $\quad$ Fiziksel çevresel etkenlerden en üst düzeyde yararlanabilecek şekilde teknik ve yasal sınırlamalara uygun ve disiplinler arası çalışmalar sonucunda gerçekleştirebilme,

○ Yapısal tasarım ve yapım yöntemleri alanlarında araştırma ve uygulama etkinlikleri gerçekleştirmek amacına yönelik olarak; performans gereksinimlerini tanımlayıp yapısal tasarım sürecini izleyerek, çözüm üretebilme,

○ Yapı malzemelerine ait iç yapı, tür ve biçim olarak değerlendirmeler yapabilme, becerilerini kazandırmaktadır, hedeflenmiştir.

Çevre Kontrolü ve Yapı Teknolojisi Yüksek Lisans Programı'nın temel araştırma alanları; Çevre Kontrolü ve Yapı Fiziği, Mimarlıkta Yapı ve Yapım Teknolojileri, Yapı Malzemesi ile Yapı ve Deprem Mühendisliği çalışma gruplarından oluşmaktadır.

Yapı Fiziği ve Çevre Kontrolü, Mimarlık Yapı Malzemesi Laboratuvarları, Mimari Koruma gibi. Mimarlık bölümüne ait laboratuvarları (Şekil 6) ile lisansüstü öğrencilerin uygulamalı çalışmalar yapabilmesine katkı sağlamaktadır. (URL-24)

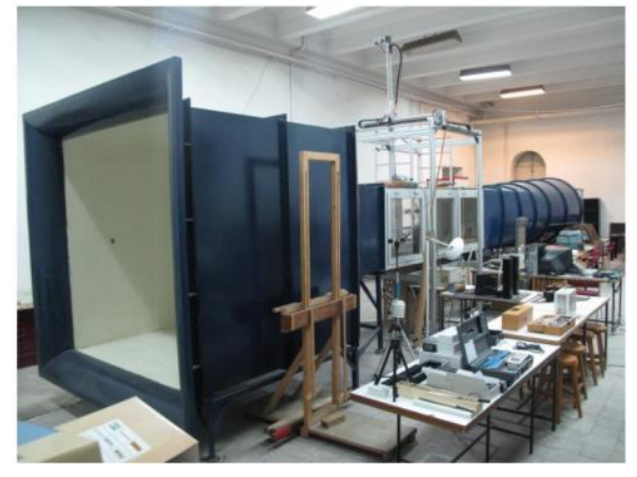

a

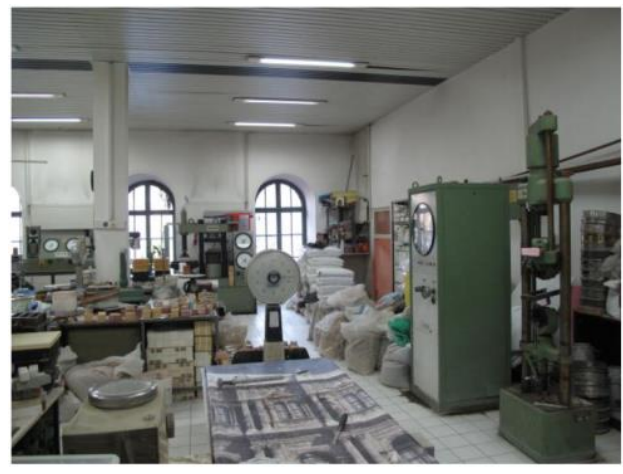

b

Şekil 6. a.Yapı Fiziği ve Çevre Kontrolü, b. Mimarlık Yapı Malzemesi Laboratuvarları (URL-24)

Program (Tablo 5), 2 akademik yıl, derslerin kredisi 60 Akts ve tez hazırlanması olarak kurgulanmıştır. Derslerin en az \%30'u İngilizce olmalıdır. Proje dersi kapsamında tez konusuna bağlı olarak belirlenen bir araştırma çalışması yapılmaktadır. En az 4 zorunlu, 4 seçmeli ve 1 seminer dersinin verilmesi gerekmektedir. Şartları sağlayan öğrenci tez aşamasına geçer. 3. yarıyıldan itibaren tez aşamasına başlanmaktadır. En fazla 6. yarıyılın sonunda tez teslimi yapılmaktadır. Toplamda 90-120 AKTS kredisi alınması gerekmektedir. (URL-16) 
Sürdürülebilirliğin Mimarlık Yüksek Lisans Programı ile Bütünleştirilmesi: Yurt Dışı ve Türkiye Örneklerinin Karşılaştırmalı Analizi

Tablo 5. İstanbul Teknik Üniversitesi, Mimarlık Ana Bilim Dalı, Çevre Kontrolü ve Yapı Teknolojisi Yüksek Lisans Program Müfredatının Analizi

\begin{tabular}{|c|c|c|c|c|c|}
\hline \multicolumn{2}{|c|}{ Dönem } & Dersin & Dersin Adl & AKTS & Durum \\
\hline \multirow{15}{*}{\multicolumn{2}{|c|}{ : N) }} & CKY501E & Yapılarda Ses Yalıtımı & 7.5 & Seçmeli \\
\hline & & CKY503E & Mimarlıkta Güneş Işı̆̆ı & 7.5 & Seçmeli \\
\hline & & CKY506 & Yapma Çevrede Enerji Korunumu & 7.5 & Seçmeli \\
\hline & & CKY511 & Endüstri Yapılarında ve Tesisat Sistemlerinde Gürültü Kontrolü & 7.5 & Seçmeli \\
\hline & & CKY515 & Bina Tipolojisine Bağlı Akustik Sorunlar & 7.5 & Seçmeli \\
\hline & & CKY517 & Binalarda Sağlık Donatımı Dizaynı & 7.5 & Seçmeli \\
\hline & & CKY527 & Yapı Hasarları ve Yap1 Koruma İlkeleri & 7.5 & Seçmeli \\
\hline & & CKY537E & Mimarlık Teknolojilerinde Araştırma Yöntemleri & 7.5 & Zorunlu \\
\hline & & CKY539 & $\begin{array}{l}\text { Bina Elemanlarında Çevresel Sürdürülebilirliğin } \\
\text { Değerlendirilmesi }\end{array}$ & 7.5 & Seçmeli \\
\hline & & CKY543 & Bina Tasarımında Yangından Korunma & 7.5 & Seçmeli \\
\hline & & CKY545E & Bina Teknolojisi: Teoriden Pratiğe & 7.5 & Seçmeli \\
\hline & & CKY547 & Cephe Malzeme ve Bileşenleri & 7.5 & Seçmeli \\
\hline & & CKY549 & Taşıyıcı Sistem Tasarımı & 7.5 & Seçmeli \\
\hline & & CKY551 & Detay Tasarımı ve Strüktür Konseptinin Entegrasyonu & 7.5 & Seçmeli \\
\hline & & CKY531 & Yapıda Malzemenin Performansı & 7.5 & Seçmeli \\
\hline \multirow{15}{*}{\multicolumn{2}{|c|}{$\Xi$}} & CKY502 & Enerji Maliyeti Düşük Bina Tasarımı & 7.5 & Seçmeli \\
\hline & & CKY504 & Bina Tipolojisine Bağlı Aydınlatma Sorunları & 7.5 & Seçmeli \\
\hline & & CKY510 & Gürültü Kontrolu Açısından Yapı Elemanları Tasarımı & 7.5 & Seçmeli \\
\hline & & CKY514 & Çevre ve Yapı Tasarımında Ses Kontrolu Yöntemleri & 7.5 & Seçmeli \\
\hline & & CKY520 & Mimarlıkta Geleneksel Yapı Malzemeleri & 7.5 & Seçmeli \\
\hline & & CKY522 & Mimarlıkta Bitirme Malzemeleri ve Uygulamaları & 7.5 & Seçmeli \\
\hline & & CKY524 & Yapı Sistemlerinde Malzeme Seçimi Yöntemleri & 7.5 & Seçmeli \\
\hline & & CKY526E & İklim ve Yapı Kabuğu Dizaynı & 7.5 & Seçmeli \\
\hline & & CKY528E & Kullanıcı İhtiyaçları ve Yapma Çevre Standartları & & Zorunlu \\
\hline & & CKY536E & Ekolojik Yapı Malzemeleri & 7.5 & Seçmeli \\
\hline & & CKY544 & Binalarda Su Etkinliği & 7.5 & Seçmeli \\
\hline & & CKY550E & Bina Teknolojisi: Sürdürülebilirlik & 7.5 & Seçmeli \\
\hline & & CKY552 & Mimarlıkta Teknoloji: İleri Teknolojik Çalışmalar & 7.5 & Seçmeli \\
\hline & & CKY546 & Hasarlı Yapıların Güçlendirilmesi & 7.5 & Seçmeli \\
\hline & & CKY548E & Mimarlıkta Çelik Yapı Tasarımı & 7.5 & Seçmeli \\
\hline \multirow{6}{*}{\multicolumn{2}{|c|}{ 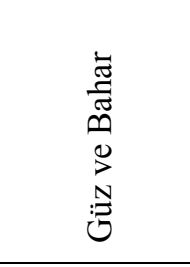 }} & CKY533 & Proje I & 7.5 & Zorunlu \\
\hline & & CKY529 & Proje II & 7.5 & Zorunlu \\
\hline & & CKY530E & Konuşma ve Müzik Salonlarının Akustik Tasarımı & 7.5 & Seçmeli \\
\hline & & CKY541E & Çevre Kontrolü ve Yapı Teknolojisinde Özel Konular & 7.5 & Seçmeli \\
\hline & & CKY596 & Bilimsel Araştırma Etik ve Seminer & 0 & Zorunlu \\
\hline & & CKY597 & Uzmanlık Alan Dersi & 0 & Zorunlu \\
\hline \multirow{3}{*}{$\begin{array}{l}\nexists \\
\dot{i}\end{array}$} & 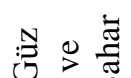 & & Tez Çalışması & & Zorunlu \\
\hline & & & Uzmanlık Alan Dersi & & Zorunlu \\
\hline & & $\begin{array}{r}\text { Sürdürüleb } \\
\text { Bağlar }\end{array}$ & $\begin{array}{l}\text { Sürdürülebilirlikle } \\
\text { Az Bağlantılı }\end{array}$ & $\begin{array}{l}\text { ilirlikle } \\
\text { tisız }\end{array}$ & \\
\hline
\end{tabular}




\subsubsection{Yıldız Teknik Üniversitesi - İstanbul}

Yıldız Teknik Üniversitesi Mimarlık Ana Bilim Dalı altında: Mimarlık Tarihi ve Kuramı, Mimari Tasarım, Konut Üretimi ve Yapım Yönetimi, Bina Araştırma ve Planlama, Bilgisayar Ortamında Mimarlık, Yapı Fiziği, Yapı, Rölöve-Restorasyon gibi Yüksek Lisans programları bulunmaktadir.

Çalışma kapsamında ele alınan Yapı Fiziği Yüksek Lisans Programı, mimaride uygun ortamlar oluşturmak üzere yapı fiziği alanında araştıran, bilgi üreten, kuram, tasarım ve uygulama ilişkisini kurabilen, ulusal ve uluslararası platformlarda söz sahibi olabilecek yapı fiziği uzmanı ve akademisyenlerinin yetişmesini hedefleyen bir programdır.

Ders kapsamında hazırlanan çalışma örneklerinden bazıları Şekil 7'de verilmektedir.
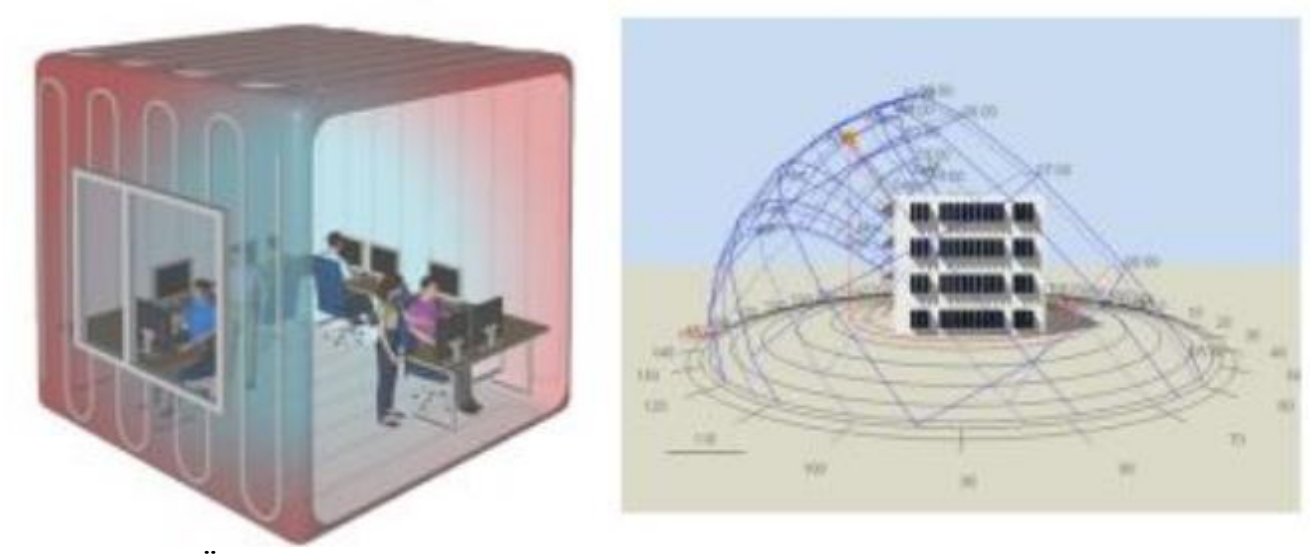

Şekil 7. YTÜ sürdürülebilir mimari yüksek lisans programı örnek çalışma görselleri (URL-17)

Program (Tablo 6), 2 akademik yıl, 21 kredilik 7 ders (en az 2 zorunlu, 5 seçmeli), 1 Araştırma yöntemleri ve bilimsel etik dersi ve 1 seminer dersinin verilmesi gerekmektedir. Şartları sağlayan öğrenci tez aşamasına geçer. 3. yarıyıldan itibaren tez aşamasına başlanmaktadır. En fazla 6. yarıyılın sonunda tez teslimi yapılmaktadır. Toplamda 90-120 AKTS kredisi alınması gerekmektedir. (URL-18) 
Tablo 6. Yıldız Teknik Üniversitesi, Mimarlık Ana Bilim Dalı, Yapı Fiziği Yüksek Lisans Program Müfredatının Analizi

\begin{tabular}{|c|c|c|c|c|c|}
\hline \multicolumn{2}{|c|}{ Dönem } & $\begin{array}{l}\text { Dersin } \\
\text { Kodu }\end{array}$ & Dersin Adr & AKTS & Durum \\
\hline \multirow{4}{*}{$\nexists$} & ט & & 3 Seçmeli ders, 1 Zorunlu ders & - & Zorunlu \\
\hline & 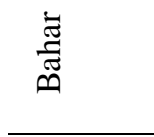 & $\begin{array}{l}\text { MIM5001 } \\
\text { MIM5004 }\end{array}$ & $\begin{array}{l}2 \text { Seçmeli ders, } 1 \text { Zorunlu ders } \\
\text { Seminer } \\
\text { Araştırma Yöntemleri ve Bilimsel Etik }\end{array}$ & $\begin{array}{l}- \\
7.5 \\
5\end{array}$ & $\begin{array}{l}\text { Zorunlu } \\
\text { Zorunlu } \\
\text { Zorunlu }\end{array}$ \\
\hline & \multirow[b]{2}{*}{ 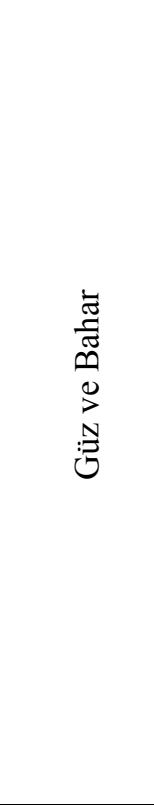 } & $\begin{array}{l}\text { MIM5105 } \\
\text { MIM5112 } \\
\text { MIM5113 } \\
\text { MIM5117 }\end{array}$ & $\begin{array}{l}\text { Aydınlık Düzenleme } 1 \\
\text { Gürültü Denetimi } 1 \\
\text { Gürültü Denetimi } 2 \\
\text { Isısal Konfor }\end{array}$ & $\begin{array}{l}7.5 \\
7.5 \\
7.5 \\
7.5\end{array}$ & $\begin{array}{l}\text { Zorunlu } \\
\text { Zorunlu } \\
\text { Zorunlu } \\
\text { Zorunlu }\end{array}$ \\
\hline & & $\begin{array}{l}\text { MIM5111 } \\
\text { MIM5104 } \\
\text { MIM5120 } \\
\text { MIM5114 } \\
\text { MIM5122 } \\
\text { MIM5123 } \\
\text { MIM5127 } \\
\text { MIM5124 } \\
\text { MIM5129 } \\
\text { MIM5121 } \\
\text { MIM5118 } \\
\text { MIM5110 } \\
\text { MIM5131 } \\
\text { MIM5119 }\end{array}$ & $\begin{array}{l}\text { Günışığı ile aydınlatma } \\
\text { Aydınlık Düzenleme } 2 \\
\text { Mimari Akustik } \\
\text { Hacim Akustiği Kuramı } \\
\text { Mimaride Güneş Enerjisi } \\
\text { Mimaride Renk } \\
\text { Renk Kuramları } \\
\text { Oditoryum Akustiği } \\
\text { Yapı Fiziği Uygulama Eleştirileri } \\
\text { Mimari Aydınlatma } \\
\text { İklim ve Tasarım Etkenleri } \\
\text { Yapılarda Edilgen Soğutma İlkeleri } \\
\text { Güneş Denetim Yöntemleri } \\
\text { Yerleşim Tasarımında Fizik Etkenler } \\
\text { Kent ve Yapı Akustiğinde Gürültü Modellemeleri }\end{array}$ & $\begin{array}{l}7.5 \\
7.5 \\
7.5 \\
7.5 \\
7.5 \\
7.5 \\
7.5 \\
7.5 \\
7.5 \\
7.5 \\
7.5 \\
7.5 \\
7.5 \\
7.5 \\
7.5 \\
\end{array}$ & $\begin{array}{l}\text { Seçmeli } \\
\text { Seçmeli } \\
\text { Seçmeli } \\
\text { Seçmeli } \\
\text { Seçmeli } \\
\text { Seçmeli } \\
\text { Seçmeli } \\
\text { Seçmeli } \\
\text { Seçmeli } \\
\text { Seçmeli } \\
\text { Seçmeli } \\
\text { Seçmeli } \\
\text { Seçmeli } \\
\text { Seçmeli } \\
\text { Seçmeli }\end{array}$ \\
\hline \multirow[t]{2}{*}{$\begin{array}{l}\nexists \\
\dot{\lambda}\end{array}$} & 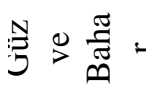 & & $\begin{array}{l}\text { Tez Çalışması } \\
\text { Uzmanlık Alan Dersi }\end{array}$ & $\begin{array}{l}20 \\
10\end{array}$ & $\begin{array}{l}\text { Zorunlu } \\
\text { Zorunlu }\end{array}$ \\
\hline & & $\begin{array}{l}\text { Sürdürüleb } \\
\text { Bağlaı }\end{array}$ & $\begin{array}{c}\text { Sürdürülebilirlikle } \\
\text { Az Bağlantılı }\end{array}$ & $\begin{array}{l}\text { ilirlikle } \\
\text { isiz }\end{array}$ & \\
\hline
\end{tabular}

\subsection{3. İzmir Yüksek teknoloji Üniversitesi - İzmir}

IYTE Mimarlık Yüksek Lisans programı, öğrencilere, mimarlık disiplinini değişik görüş açılarından inceleyebilme firsatı sunmaktadır. Programın çalışma alanları, tasarımda biliş ve biliş çalışmaları, yapı fiziği (enerji etkin tasarım, aydınlatma, akustik), mimarlık tarihi, kuramı ve eleştirisi, kinetik mimarlık (hareketli sistemler), mimarlıkta mesleki organizasyona dair ilkeler, proje ve yapım yönetimi, ve sürdürülebilir mimarlığı kapsamaktadır. (URL-19)

Mimarlık bölümüne ait lisans ve lisansüstü çalışmalar için kurulmuş yapı fiziği laboratuvarı, bilgisayar laboratuvarı ile metal, ahşap ve seramik işleri atölyelerini barındıran bir alt yapıya sahiptir. Yapı Fiziği laboratuvarı görseli ve kullanılan malzemeler Şekil 8'de verilmiştir. 
Gökşen, F., Ayçam, I., Bekler, C., Uluslararası Doğu Anadolu Fen Mühendislik ve Tasarım Dergisi / International Journal of Eastern Anatolia Science Engineering and Design (IJEASED)

(2020) 2(2):401-433

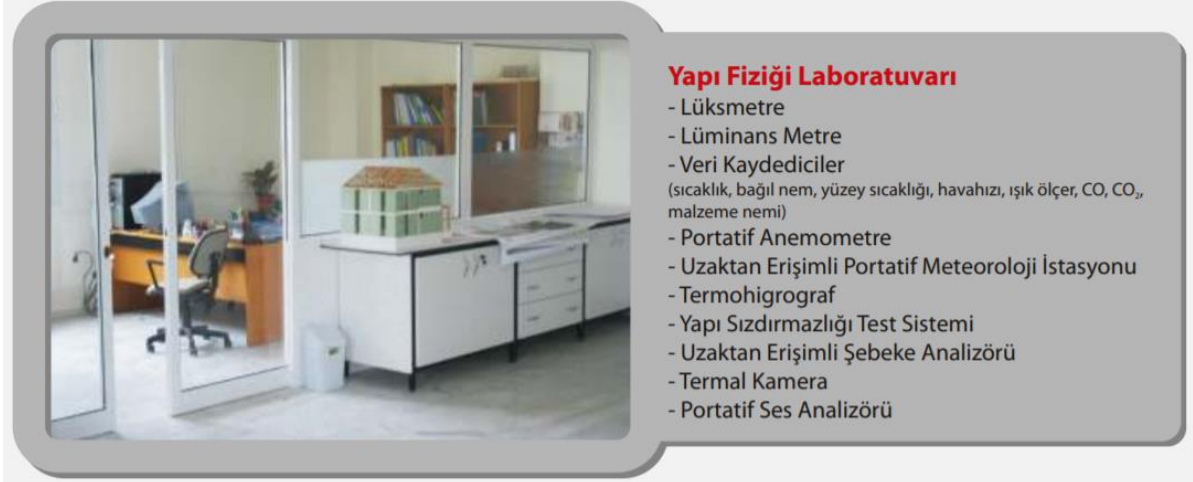

Şekil 8. IYTE Yapı Fiziği Laboratuvarı (URL-20)

Program (Tablo 7), 2 akademik yıl, öğrenciler 4 zorunlu seçmeli dersden en az 1'i olmak üzere toplamda 21 kredilik 7 ders, 1 Araştırma yöntemleri dersi ve 1 seminer dersinin verilmesi gerekmektedir. Şartları sağlayan öğrenci tez aşamasına geçer. Mimarlık Yüksek Lisans programı en az üç, en fazla altı yarıyıl sürmektedir.

Tablo 7. IYTE, Mimarlık Ana Bilim Dalı Yüksek Lisans Program Müfredatının Analizi

\begin{tabular}{|c|c|c|c|c|}
\hline Dönem & $\begin{array}{l}\text { Dersin } \\
\text { Kodu }\end{array}$ & Dersin Adr & AKTS & Durum \\
\hline \multirow{25}{*}{ 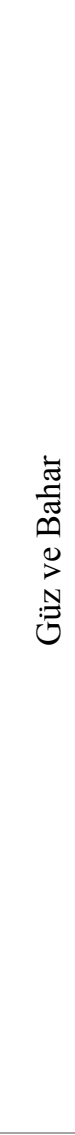 } & AR 501 & Araştırma Yöntemleri I: Mimarlık Araştırma Alanlarına Giriş & 8 & Zorunlu \\
\hline & AR 526 & Seminer & 9 & Zorunlu \\
\hline & AR 523 & *Mimarlık Tarih Yazımına Giriş & 8 & Zorunlu \\
\hline & AR 540 & *Mimarlıkta Sosyo-Kültürel Çalışmalar & 8 & Zorunlu \\
\hline & AR 553 & *Proje Yönetimi & 8 & Zorunlu \\
\hline & AR 581 & *Yapı Fiziği Temel İlkeleri & 8 & Zorunlu \\
\hline & AR 502 & Tez Araştırması & 7 & Seçmeli \\
\hline & AR 602 & Araştırma Yöntemleri II: Nitel ve Nicel Yaklaşımlar & 7 & Seçmeli \\
\hline & AR 511 & Mimari Tasarım Araştırmaları I & 7 & Seçmeli \\
\hline & AR 514 & Mimari Tasarım Araştırmaları II & 7 & Seçmeli \\
\hline & AR 517 & Türkiye'de Konut & 7 & Seçmeli \\
\hline & AR 518 & 20. YY Mimarisinde Cam & 7 & Seçmeli \\
\hline & AR 519 & Mekan Üzerine Yazmak & 7 & Seçmeli \\
\hline & AR 520 & $\begin{array}{l}\text { Tarihsel Değişim ve Mimarlık Kuramı: Endüstriyel Devrimden } \\
\text { Post-Modernizme }\end{array}$ & 7 & Seçmeli \\
\hline & AR 521 & Mimaride Çağdaş Yönelimler & 7 & Seçmeli \\
\hline & AR 522 & Mimari Tasarım Yaklaşımları & 7 & Seçmeli \\
\hline & AR 524 & Postmodernizm ve Mimarlık Kuramı & 7 & Seçmeli \\
\hline & AR 525 & Mimarlık Özel Konular & 7 & Seçmeli \\
\hline & AR 534 & Mimaride Hareketli Taşıyıcı Sistemler & 7 & Seçmeli \\
\hline & AR 535 & Çelik ve Ahşap Yapılar & 7 & Seçmeli \\
\hline & AR 545 & Tasarımda Bilişsel Unsurlar & 7 & Seçmeli \\
\hline & AR 546 & Tasarımda Reprezantasyon Sistemleri & 7 & Seçmeli \\
\hline & AR 547 & Güncel Mimari ve Kentsel Tasarım Süreçleri & 7 & Seçmeli \\
\hline & AR 548 & Yaşanan Mekan:Kentselin Keşfi & 7 & Seçmeli \\
\hline & AR 549 & Mekânı Anlamak & 7 & Seçmeli \\
\hline
\end{tabular}




\begin{tabular}{lllll} 
AR 552 & Gayri Menkul Geliştirme & 7 & Seçmeli \\
\hline AR 555 & Çatışma Yönetimi ve Uzlaşma Teknikleri & 7 & Seçmeli \\
\hline AR 556 & Toplam Kalite Yönetimi & 7 & Seçmeli \\
\hline AR 557 & Proje Planlaması ve Kontrolü & 7 & Seçmeli \\
\hline AR 558 & Tasarım İnşaat Firmaları İçin Stratejik Yönetim & 7 & Seçmeli \\
\hline AR 559 & İnşaat Projeleri İçin İşlemler Yönetimi & 7 & Seçmeli \\
\hline AR 562 & Mimarlik ve Bilim & 7 & Seçmeli \\
\hline AR 564 & Mimari Antropoloji Çalışmaları & 7 & Seçmeli \\
\hline AR 571 & Sürdürülebilir Mimarlık & 7 & Seçmeli \\
\hline AR 572 & Mekânın Analitik Okunması I & 7 & Seçmeli \\
\hline AR 573 & Mekânın Analitik Okunması II: Uygulamalar & 7 & Seçmeli \\
\hline AR 582 & Enerji Etkin Tasarım & 7 & Seçmeli \\
\hline AR 583 & Günışı̆ı Tasarımı ve Analizi Temel İlkeleri & 7 & Seçmeli \\
\hline AR 584 & Bina Enerji Simülasyonuna Giriş & 7 & Seçmeli \\
\hline AR 585 & Binalarda Enerjinin Temelleri & 7 & Seçmeli \\
\hline AR 586 & Binalarda Isı Transferi & 7 & Seçmeli \\
\hline AR 587 & Mimarlıkta Akustik & 7 & Seçmeli \\
\hline AR 588 & Bina Uygulamalarında Sayısal Isı Geçişi ve Akışa Giriş & 7 & Seçmeli \\
\hline AR 589 & Enerji Etkin Aydınlatma Tasarımı & 7 & Seçmeli \\
\hline AR 590 & Bütünleşik Tasarım ve Yapı Bilgi Modelleme & 7 & Seçmeli \\
\hline AR 591 & Mimarlık, Modernite ve Kimlik & 7 & Seçmeli \\
\hline AR 592 & Hesaplamalı Mimarlıkta Pratik ve Kuramlar & 7 & Seçmeli \\
\hline AR 593 & Tasarımda Analojik Düšünme & 7 & Seçmeli \\
\hline AR 594 & Sayısal Tasarım için Temel Programlama & 7 & Seçmeli \\
\hline AR 595 & Kırsal Dönüşüm ve Yapılı Çevre & 7 & Seçmeli \\
\hline AR 621 & İzmir’de Mimari & 7 & Seçmeli \\
\hline AR 626 & Oryantalizm & 7 & Seçmeli \\
\hline AR 632 & Kinetik Strüktürlerin Analizi & 7 & Seçmeli \\
\hline & & & \\
\hline
\end{tabular}

\begin{tabular}{|c|c|c|c|c|}
\hline \multirow{2}{*}{ 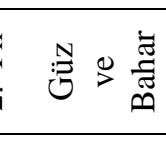 } & AR 500 & Yüksek Lisans Tezi & 26 & Zorunlu \\
\hline & AR 8XX & Uzmanlık Alanı Calışmaları & & Zorunlu \\
\hline & $\begin{array}{r}\text { Sürdürül } \\
\text { Bağl }\end{array}$ & $\begin{array}{l}\text { Sürdürülebilirlikle } \\
\text { Az Bağlantılı }\end{array}$ & $\begin{array}{c}\text { Sürdürülebilirlikle } \\
\text { Bağlantısız }\end{array}$ & \\
\hline
\end{tabular}

\subsubsection{Gazi Üniversitesi Mimarlık Fakültesi, Ankara}

Gazi Üniversitesi Mimarlık Fakültesi, yüksek lisans programı mimarlık anabilim dalı altında yer almaktadır. Programda (Tablo 8), toplam 21 kredilik (52,5 Akts) 7 ders, Araştırma teknikleri ve yayın etiği, 1 seminer dersinin verilmesi gerekmektedir. Şartları sağlayan öğrenci tez aşamasına geçer. 3. yarıyıldan itibaren tez aşamasına başlanmaktadır. Mimarlık Yüksek Lisans programı en az üç, en fazla altı yarıyıl sürmektedir. (URL-21) 
Gökşen, F., Ayçam, I., Bekler, C., Uluslararası Doğu Anadolu Fen Mühendislik ve Tasarım Dergisi / International Journal of Eastern Anatolia Science Engineering and Design (IJEASED)

(2020) 2(2):401-433

Tablo 8. Gazi Üniversitesi, Mimarlık Ana Bilim Dalı Yüksek Lisans Program Müfredatının Analizi

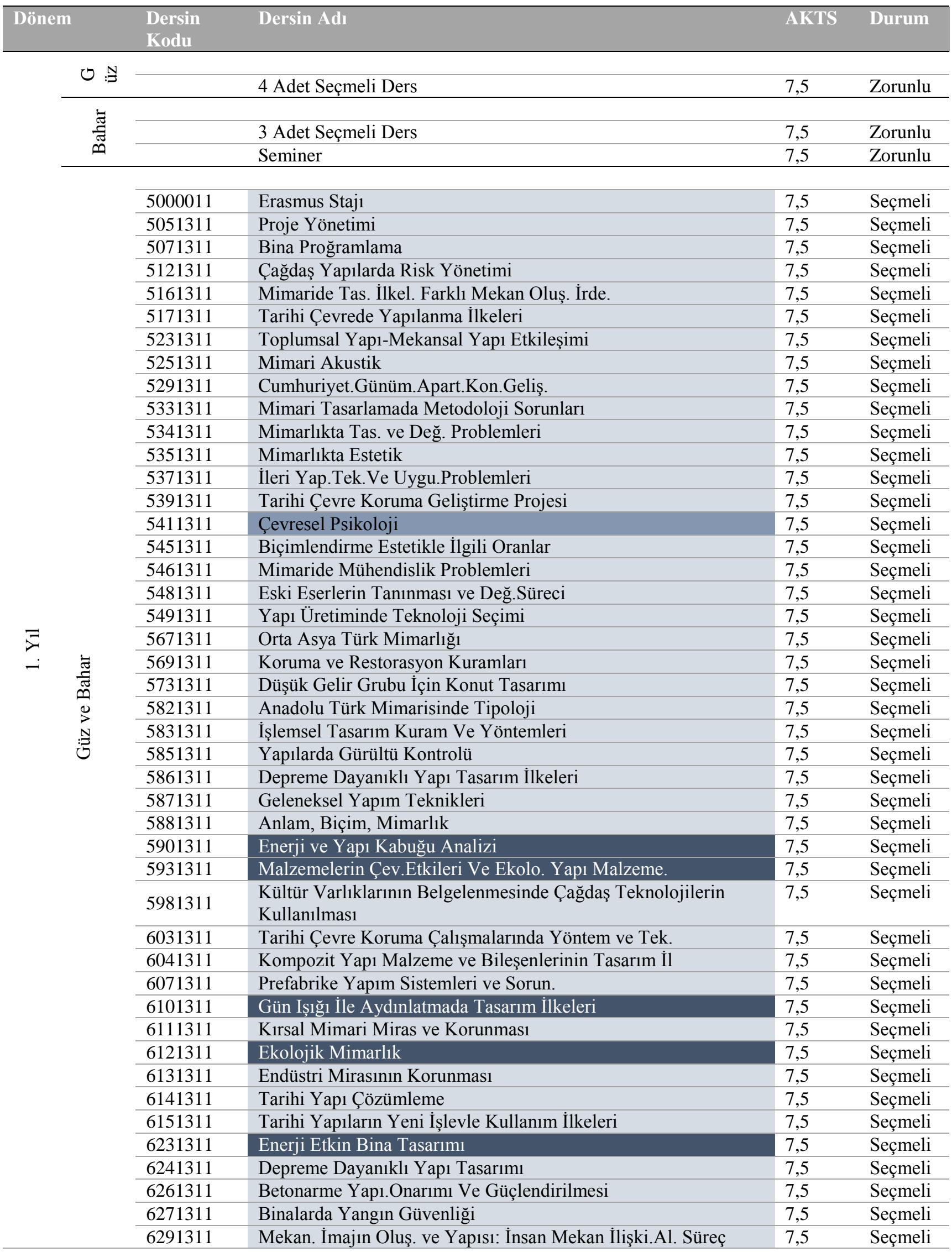




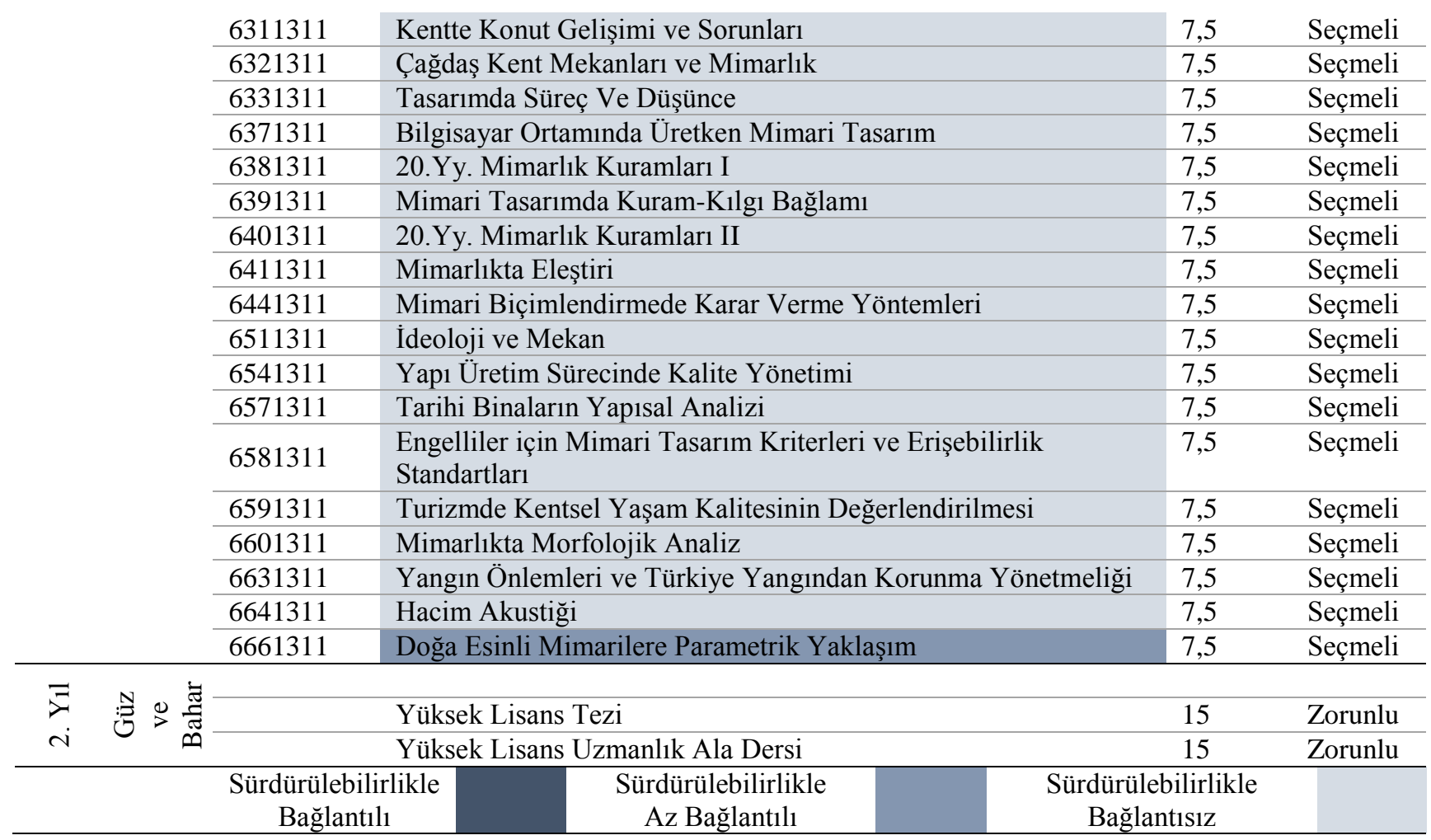

\subsubsection{Gebze Teknik Üniversitesi - Gebze / Kocaeli}

Gebze Teknik Üniversitesi, Mimarlık Fakültesi, Mimarlık Anabilim Dalı Yüksek Lisans Programında öncelikli olarak çalışma yürütülecek alanlar; Mimari Tasarım, Yapı Bilgisi, Restorasyon, Mimarlık Tarihidir.

Çalışma kapsamında ele alınacak olan Yapı Bilgisi yüksek lisans programı altında sürdürülebilir/enerji etkin mimarlık konularında alacağı dersler ile öğrencilerin, toplumsal ve çevresel sorunlara karşı duyarlı, yapı ve çevre konusunda iyileşme ve gelişmeye önem veren araştırmalar sürdürmeleri ve çözümler üretmeleri beklenmektedir (URL-22).

Bölümün bünyesinde hizmet veren yapı malzemeleri laboratuvarı ve mimarlık hesaplamalı simülasyon laboratuvarı uygulamalı çalışma yapan öğrencilerin faydalanabilmeleri açısından önemlidir (URL-26).

Program (Tablo 9), 2 akademik yıl, tezli yüksek lisans programı için toplam 120 AKTS olarak kurgulanmıştır. Öğretim dili Türkçedir ve tam zamanlı eğitim verilmektedir. Öğrencinin mezuniyet koşulunu sağlayabilmesi için en fazla dört yarıyıl sonunda kredili derslerini ve seminerlerini başarıyla tamamlaması ve en fazla 6. yarıyılın sonunda tez tesliminin yapılması gerekmektedir (URL-23). 
Gökşen, F., Ayçam, I., Bekler, C., Uluslararası Doğu Anadolu Fen Mühendislik ve Tasarım Dergisi / International Journal of Eastern Anatolia Science Engineering and Design (IJEASED)

(2020) 2(2):401-433

Tablo 9. GTÜ Mimarlık Yüksek lisans programı dersleri (URL-22)

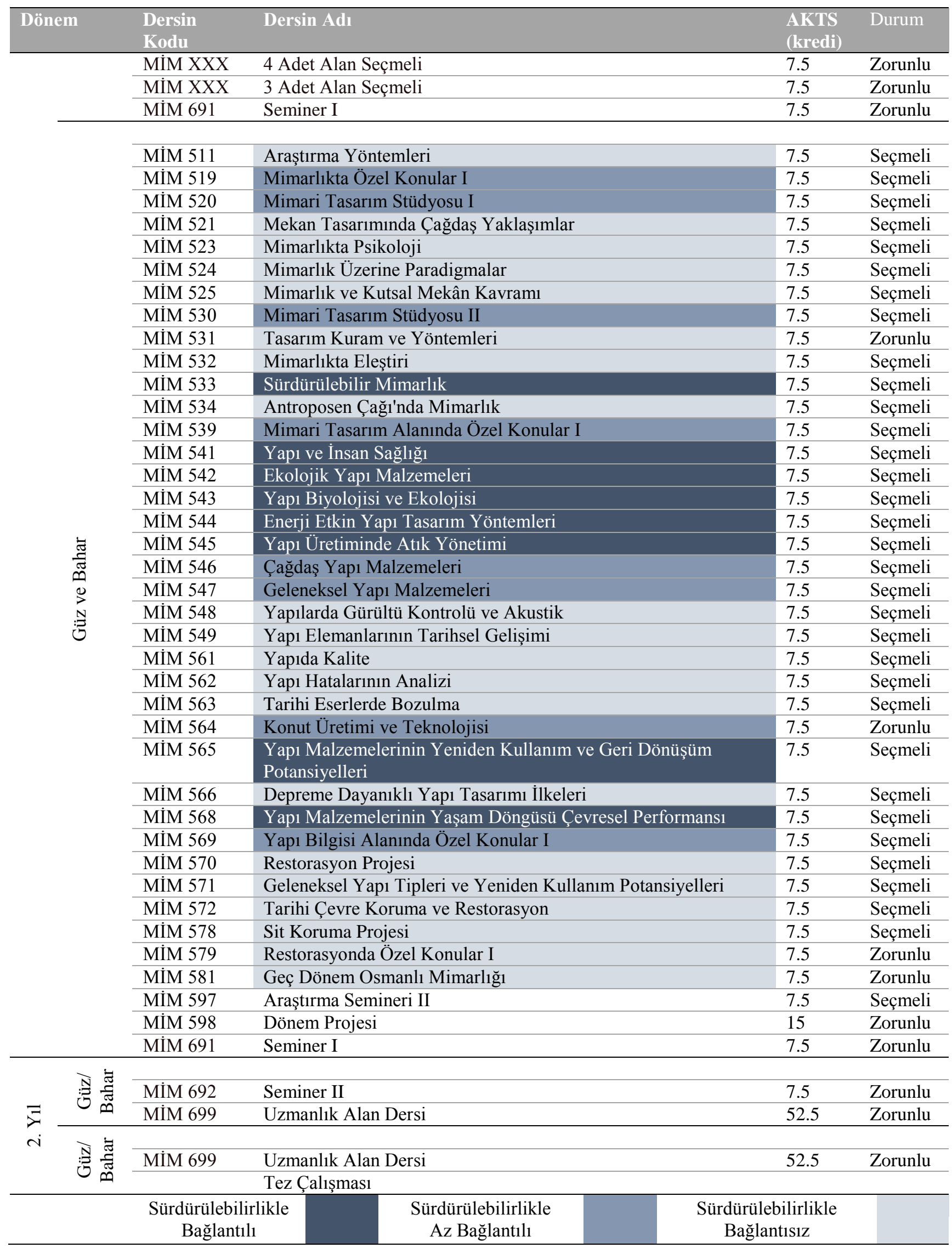




\subsubsection{Müfredat Analizi Sonucu Ders Durumları}

İstanbul Teknik Üniversitesi Mimarlık Ana Bilim Dalı altında yer alan Çevre Kontrolü ve Yap1 Teknolojisi Yüksek Lisans Programı, çevre üzerine özelleşmiş bir program olarak \%29 oranında sürdürülebilirlikle bağlantılı, \%17 oranında sürdürülebilirlikle az bağlantılı ve \%53 oranında sürdürülebilirlikle bağlantılı olmayan derslerden oluşmaktadır (Şekil 9).

Yıldız Teknik Üniversitesi Mimarlık Ana Bilim Dalı altında yer alan Yapı Fiziği Yüksek Lisans Programı, \%37 oranında sürdürülebilirlikle bağlantılı, \%5 oranında sürdürülebilirlikle az bağlantılı ve \%58 oranında sürdürülebilirlikle bağlantılı olmayan derslerden oluşmaktadır (Şekil 9).

İzmir Yüksek teknoloji Üniversitesi, Mimarlık Yüksek Lisans programı, özelleşmiş bir anabilim dalı olmayıp, \%18 oranında sürdürülebilirlikle bağlantılı, \%9 oranında sürdürülebilirlikle az bağlantılı ve $\% 73$ oranında sürdürülebilirlikle bağlantılı olmayan derslerden oluşmaktadır (Şekil 9).

Gazi Üniversitesi Mimarlık Fakültesi, Mimarlık Ana Bilim Dalı Yüksek Lisans programı, özelleşmiş bir anabilim dalı olmayıp, \%10 oranında sürdürülebilirlikle bağlantılı, \%3 oranında sürdürülebilirlikle az bağlantılı ve \%87 oranında sürdürülebilirlikle bağlantılı olmayan derslerden oluşmaktadır (Şekil 9).

Gebze Teknik Üniversitesi, Mimarlık Fakültesi, Yapı Bilgisi Yüksek Lisans programı, yap1 bilgisi üzerine özelleşmiş bir anabilim dalı olarak, \%23 oranında sürdürülebilirlikle bağlantılı, \%23 oranında sürdürülebilirlikle az bağlantılı ve \%54 oranında sürdürülebilirlikle bağlantılı olmayan derslerden oluşmaktadır (Şekil 9).

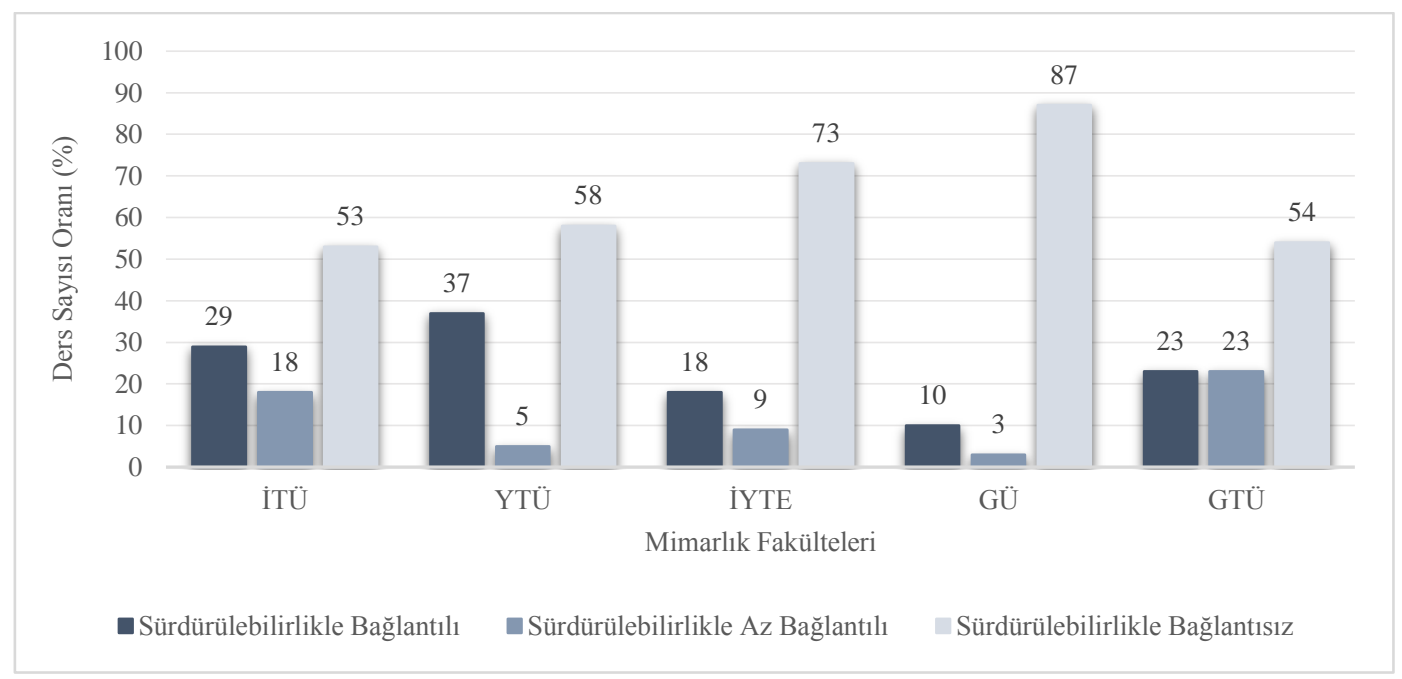

Şekil 9. Türkiye'den Seçilen Üniversitelerin, Mimarlık Yüksek Lisan Programı Müfredat Analizleri Sonucu Sürdürülebilirlikle Bağlantılı Ders Durumları 


\section{Bulguların Değerlendirilmesi}

Yurt dışından ve Türkiye'den seçilen üniversitelerdeki mimarlık bölümü yüksek lisans programlarının işleyişleri ve müfredatları değerlendirilmiş, bu değerlendirmeler sonucunda: akademik yıl, mimarlık anabilim dalı veya kürsülere ayırılan özelleşmiş anabilim dalı, derslerin sürdürülebilirlikle ilişkili olma durumları, stüdyo proje çalışması, uygulamalı stüdyo proje çalışması, enerji simülasyon programları, tez çalışması, laboratuvar olanakları, sertifika verilmesi, alana yönelik destek kursları, yaz okulu destek kursları, yurtdışı eğitim olanakları gibi farklılıkların tespit edildiği alt parametreler belirlenmiş (Tablo 10) ve bu parametreler üzerinden karşılaştırılmıştır.

Yüksek lisans programlarının akademik yıl bazında süreçleri incelendiğinde: Yurt dışında, öğrencilerin lisans düzeyinde aldıkları eğitime göre 2 veya 3 yıl olarak farklılık göstermekte olup eksik oldukları bölümleri tamamlayacakları şekilde müfredat şekillendirilmiştir. Türkiye'de 2 yıl olarak sabitlenmiş durumdadır.

Yurt Dışından seçilen üniversitelerden sadece Kansas Üniversitesi Mimarlık Anabilim dalı, diğer üniversiteler kürsülere ayrılmış; Sürdürülebilir Mimarlık, Mimarlık ve Enerji yüksek lisans programları gibi özelleşmiş ana bilim dalları kurulmuştur. Türkiye'deki Üniversitelerde genelikle Mimarlık Ana Bilim Dalı altında eğitim verilmekte olup seçtiğimiz üniversitelerden, İTÜ, YTÜ ve GTÜ bu kapsamda yer almayarak farklı ana bilim dallarını bünyelerinde barındırmaktadırlar. Bunlar; Yapı Fiziği, Çevre Kontrolü ve Yapı Teknolojisi ve Yapı Bilgisi yüksek lisana programlarıdır. Bunların dışında farklı ana bilim dalları da bulunmakta olup çalışma kapsamında sadece sürdürülebilirlik konuları ile bağlantılı derslerin yer aldığı ana bilim dalları dikkate alınmıştır.

Üniversitelerin ana bilim dalı olarak özelleşmiş bir sisteme sahip olması, müfredatlarında yer alan derslerin kapsamını șekillendirmektedir. Tablo 10'da ana bilim dalı olarak ayrılan üniversitelerin sürdürülebilirlikle bağlantılı ders yüzdelerine bakıldığında oranın daha yüksek, sürdürülebilirlikle bağlantısız ders yüzdelerinin ise daha düşük olduğu görülmektedir. Bu noktada da Kansas üniversitesi farklılaşarak mimarlık ana bilim dalı altında eğitim verilmesine rağmen sürdürülebilirlikle bağlantılı ve bağlantısız ders sayısının eşit oranlarda olması dikkat çekicidir. $\mathrm{Bu}$ durum, üniversitenin günceli takip ederek müfredatlarını yenilemeleri gerektiğine güzel bir örnek teşkil etmektedir. Türkiye'de ise ana bilim dalı olarak ayrılmasına rağmen sürdürülebilirlikle 
bağlantılı ders oranların Yurt dışına göre daha düşük olduğu görülmektedir. Bunun nedeni örneğin; yapı fiziğinde sadece sürdürülebilirlik değil onun dışında, akustik, aydınlatma gibi konu başlıklarının dersleri de yer almaktadır. Yani Yurt dışındaki gibi tamamen sürdürülebilir mimarlık veya enerji gibi spesifik bir ana bilim dalı bulunmamaktadır. Mimarlık yüksek lisans programında ise, müfredat çok fazla çalışma alanını barındırdığından dolayı sürdürülebilirlikle bağlantılı olan ders oranı düşük çıkmıştır.

Stüdyo Projesi dersi, Yurt dışındaki tüm üniversitelerde mevcuttur. Öğrenciler, farklı konseptlerle oluşturulan atölyelerden çalışma alanlarına uygun olanı seçerek edindikleri teorik bilgileri, tasarımla birleştirip uygulamaya dökme imkanı bulmaktadırlar. Türkiye’deki üniversitelerde yüksek lisans düzeyinde stüdyo projesine yer veren üniversiteler olmakla birlikte her üniversite yer verilmemiştir.

Uygulamalı Stüdyo Projesi kapsamında: Kansas Üniversitesinde, uygulamalı proje tasarım stüdyosu olan Stüdyo 804'te eğitim alan öğrenciler, yap1 inşası, detay çizimlerinin geliştirilmesi, yapı malzemelerin uygulanışı ve bunları yaparken yetkililerle doğrudan iletişimde oldukları için disiplinler arası işbirliği gibi becerileri kazanarak sürdürülebilir tasarım ilkeleri ile bütünleştirdikleri projelerini hayata geçirmiş olurlar (Şekil 10). Norveç Bilim ve Teknoloji Üniversitesinde ise proje çalışması kapsamında, alternatif yenilenebilir enerji sistemlerinin entegrasyonu ile binanın çevresel performansını optimize eden bütünleşik tasarım süreçlerinin geliştirilmesi konusunda eğitim verilmektedir. Bu dönemde öğrenciler ZEN araştırma merkezi ile bağlantılı olarak çalışmakta olup yüksek lisans tezinin geliştirilmesi için ön çalışmaları bu aşamada oluşturmaktadırlar. Bu işleyiş öğrencilerin binaların çevresel performansını optimum koşullarda sağlayabilecek arge çalışmalarında bulunmalarına teşvik etmektedir. Bu iki üniversite dışında hiçbir üniversitede de uygulamalı stüdyo projesi yer almamaktadır.

Stüdyo 804 kapsamında öğrencilerin uyguladıkları binaların tümü, ABD Yeşil Bina Konseyi'nden LEED Platinum sertifikalarına sahiptir. $\mathrm{Bu}$ yönü ile Kansas Üniversitesi, sürdürülebilir tasarım kriterlerinin mimarlık eğitimine entegrasyonu kapsamında diğer üniversitelerden önemli derecede farklılaşmakta ve öne çıkmaktadır. 

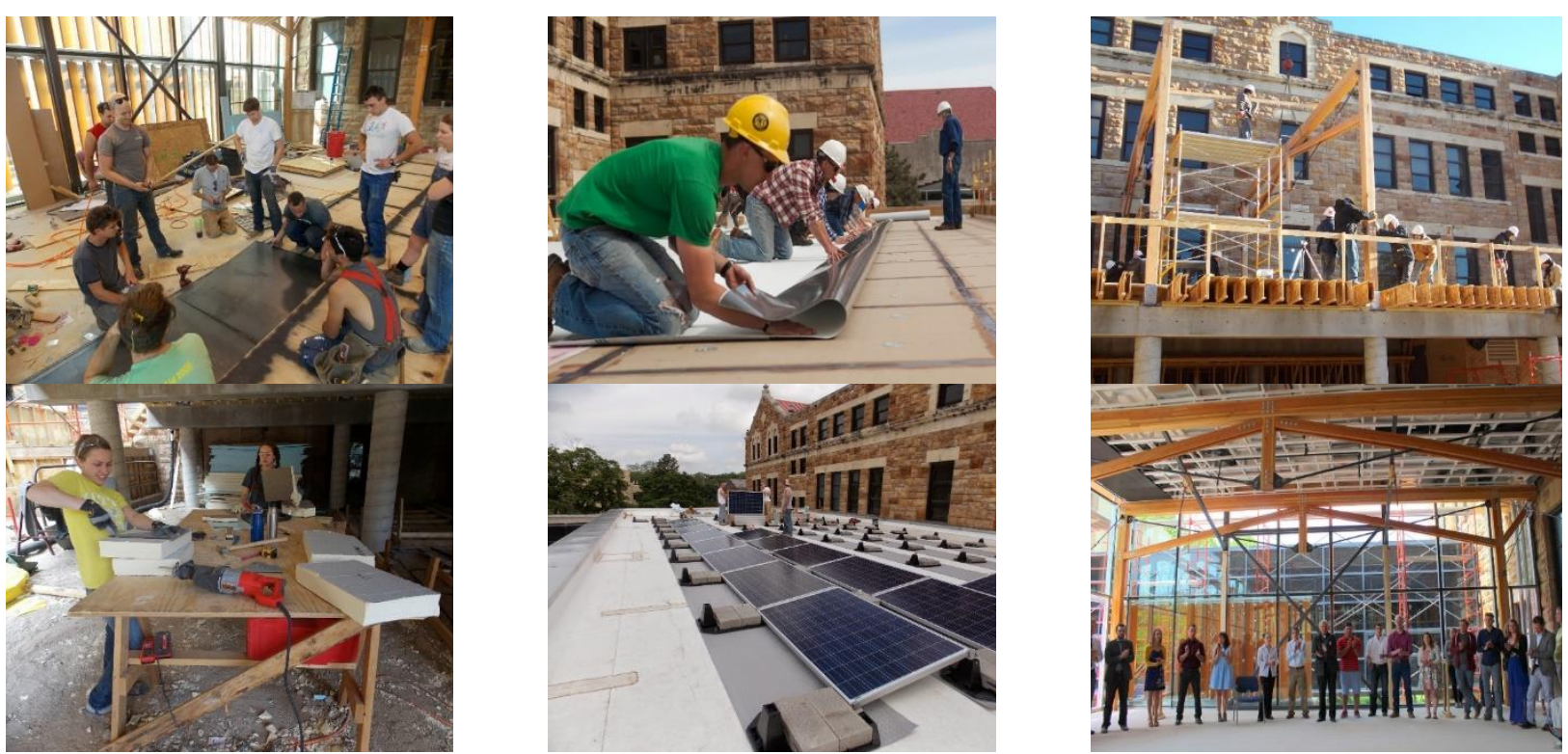

Şekil 10. Stüdyo 804, 2014 Açık Ev Sınıfı Şantiye Fotoğrafları (URL-25)

Simülasyon programları, Yurt dışında ve Türkiye'de, bazı üniversitelerde var iken bazılarında yoktur. Müfredatlarında yer alan örnek olarak verilebilecek dersler: BIM, Bina ve yazılım kullanımında enerji simülasyonu, Bina Enerji Simülasyonudur. İncelenen üniversitelerde, proje vb. gibi derslerde simülasyon programları ile ilgili içeriklere rastlanmış olup destek amaçlı kullanıldığı ve ayrı bir ders olarak verilmediği görülmüştür.

Tez çalışması, Kansas Üniversitesi hariç tüm üniversitelerde mevcuttur. Ancak, Thomas Jefferson Üniversitesi farklı olarak tez çalışması yerine, dönem projesi ve seçmeli ders gibi bir alternatif geliştirmiştir. Türkiye'de alternatifsiz hepsinde zorunlu olarak tez çalışması bulunmaktadir.

Laboratuvar olanakları yurt dışında yer alan tüm üniversitelerde mevcuttur. Türkiye'de Teknik ve Teknoloji Üniversiteleri tarafından mimarlık bölümüne özel laboratuvar imkanları sağlanabilmektedir fakat Türkiye genelinde bir inceleme yapılacak olsa çoğu üniversitenin bu konuda eksik olduğu görülecektir.

Yurt dışında uygulanan Sertifika sistemi ile öğrenciler, alanlarında uzman olarak çalışma imkanı bulmaktadırlar. Uzmanlaşma sistemi Kansas Üniversitesinde ve Thomas Jefferson Üniversitesinde uygulanmaktadır. TJÜ’de biraz farklı bir sistem söz konusudur. Lisansüstü eğitimi dışında da 6-12 aylık sertifika eğitimleri ile öğrenciler programın gerektirdiği zorunlu ders kredisini tamamlayarak katıldığı programın sertifikasını alabiliyor. Bu programlar ile alınan sertifikalara örnek olarak: Yaşayan Bina Tasarımı, Esnek (Dirençli) Toplulukların Tasarımı, Sürdürülebilirlik Liderliği, Yeşil Bina Operasyonları, Pasif Ev Tasarımı Sertifikaları verilebilir. Öğrenciler yüksek 
lisans programına başvurup kabul edilmeleri halinde sertifika kursları yoluyla kazanılan kredilerini kullanarak eğitime devam edip yüksek lisans eğitimini tamamlama imkanı elde ediyorlar. Türkiye'deki üniversitelerde ise herhangi bir sertifika eğitimi bulunmamaktadır.

Kansas Üniversitesinde müfredat analizi başlığ 1 altında tanımlanmış olan kriterlere uygun olan öğrenciler eksiklerini tamamlamak için kurslara tabi tutulmaktadır ve Thomas Jefferson Üniversitesinde de uzmanlaşmaya yönelik destek kursları verilmektedir. Ayrıca Kansas Üniversitesinde yaz döneminde yurtdışı mimarlık çalışmalarına imkan tanınmaktadır. Diğer üniversitelerde bu kapsama Erasmus programı dahil edilebilir. Türkiye'deki üniversitelerde destek kursları bulunmamaktadır.

Tablo 10. Mimarlık Bölümü Yüksek Lisans Programlarının Karşılaştırma Tablosu

\begin{tabular}{|c|c|c|c|c|c|c|c|c|c|c|}
\hline \multirow{2}{*}{\multicolumn{2}{|c|}{ PARAMETRELER }} & \multicolumn{4}{|c|}{ YURT DIŞI ÜNIVERSITELERİ } & \multicolumn{5}{|c|}{ TÜRKIYE ÜNIVERSITELERI } \\
\hline & & $\begin{array}{l}\text { KANSA } \\
\text { S U }\end{array}$ & NTNU & TJU & $\begin{array}{l}\text { TEH } \\
\text { RAN } \\
\text { U. }\end{array}$ & İTÜ & YTÜ & İYTE & $\begin{array}{l}\text { GAZİ } \\
\text { Ü. }\end{array}$ & GTÜ \\
\hline \multicolumn{2}{|c|}{ Akademik Yılı } & $2-3$ & 2 & 2 & 3 & 2 & 2 & 2 & 2 & 2 \\
\hline \multicolumn{2}{|c|}{$\begin{array}{l}\text { Mimarlık Ana Bilim Dalı Altında } \\
\text { Özelleşmiş Yüksek Lisans } \\
\text { Programı Olması }\end{array}$} & Hayır & Evet & Evet & Evet & Evet & Evet & Hayır & Hayır & Evet \\
\hline \multirow{3}{*}{\multicolumn{2}{|c|}{$\begin{array}{ll}\text { Ders } & \text { Sürdürülebilirlikle } \\
\text { Durumları } & \text { az bağlantılı ders } \\
& \text { yüzdesi } \\
& \text { Sürdürülebilirlikle } \\
& \text { bağlantısız ders } \\
& \text { yüzdesi }\end{array}$}} & $\% 48$ & $\% 67$ & $\% 98$ & $\% 67$ & $\% 29$ & $\% 37$ & $\% 18$ & $\% 10$ & $\% 23$ \\
\hline & & $\% 4$ & $\% 20$ & $\% 8$ & $\% 20$ & $\% 18$ & $\% 5$ & $\% 9$ & $\% 3$ & $\% 23$ \\
\hline & & $\% 48$ & $\% 0$ & $\% 3$ & $\% 13$ & $\% 53$ & $\% 58$ & $\% 73$ & $\% 87$ & $\% 54$ \\
\hline \multicolumn{2}{|c|}{ Stüdyo Proje Çalışması } & Evet & Evet & Evet & Evet & Evet & Evet & Hayır & Hayır & Evet \\
\hline \multicolumn{2}{|c|}{ Uygulamalı Stüdyo Proje Çalış. } & Evet & Evet & Hayır & Hayır & Hayır & Hayır & Hayır & Hayır & Hayır \\
\hline \multicolumn{2}{|c|}{ Enerji Simülasyon Programları } & Hayır & Hayır & Evet & Evet & Hayır & Hayır & Evet & Hayır & Evet \\
\hline \multicolumn{2}{|c|}{ Tez Çalışması } & Hayır & Evet & Evet & Evet & Evet & Evet & Evet & Evet & Evet \\
\hline \multicolumn{2}{|c|}{ Laboratuvar Olanakları } & Evet & Ever & Evet & Evet & Evet & Evet & Evet & Hayır & Evet \\
\hline \multicolumn{2}{|c|}{ Sertifika Verilmesi } & Evet & Hayır & Evet & Hayır & Hayır & Hayır & Hayır & Hayır & Hayır \\
\hline \multicolumn{2}{|c|}{ Alana Yönelik Destek Kursları } & Evet & Hayır & Evet & Hayır & Hayır & Hayır & Hayır & Hayır & Hayır \\
\hline \multicolumn{2}{|c|}{ Yaz Okulu Destek Kursları } & Evet & Hayır & Hayır & Hayır & Hayır & Hayır & Hayır & Hayır & Hayır \\
\hline \multicolumn{2}{|c|}{ Yurtdışı Eğitim Olanakları } & Evet & Evet & Evet & Evet & Evet & Evet & Evet & Evet & Evet \\
\hline
\end{tabular}




\section{4. Öneriler}

Dünyadaki son durum kendini yenileme ve güncelleme konusunda üst düzeyde duyarlılık gösterilmesi gerektiği prensibine dönmüş durumdadır. Türkiye’deki eğitim sistemine bakıldığında ise yenilik ve dönem gereklilikleri ile harekete geçme anlamında ağır davranıldığı düşünülmektedir. Çalışma kapsamda mimarlık bölümü yüksek lisans programı müfredatlarının tekrar gözden geçirilmesi ve sürdürülebilirlik konularının dahil edilmesi için gerekli güncellemelerin yapılması gündeme getirilmek istenmiştir. Sunulan öneriler aşağıda yer almaktadır:

Yüksek lisans programlarının farklı ana bilim dallarına ayrılması, o alan ile ilgili daha fazla içerik sağlamak, uzmanlık alanı oluşturmak ve bu kapsamda uzman yetiştirmek için önemli bir adım olacaktır. Program, Mimarlık ana bilim dalı olarak kalmak zorundaysa bile günümüz koşullarında küresel gelişmeler ön planda olan, günden güne önemi artan, mimarlığı doğrudan etkileyen bir konudur. Enerji ile ilgili konularda, Enerji Ekonomisi ve Enerji Politikası gibi derslere müfredatlarında çok rastlanmamış olup eklenmesi gerektiği düşünülmektedir.

Tasarım stüdyosu, mimarlık eğitiminde tüm konuların çözüldüğü bir havuzu oluşturmaktadır. Stüdyo, problem çözme pratiği çevresinde modellenen kendine özgü bir öğrenme ortamı yaratarak karakterize edilir. Yüksek lisans eğitiminde sürdürülebilirliğin proje stüdyosu ile bütünleştirilerek teoride edinilen bilgilerin tasarımla birleşip uygulamaya dökülmesi, öğrencilerin sürdürülebilir kararlar vermesi, profesyonel gelişimini desteklemesi bakımından oldukça önemli bir yere sahiptir. $\mathrm{Bu}$ nedenle mimarlık eğitimi yüksek lisans programı müfredatlarına stüdyo proje çalışmasını eklenmelidir.

Yurt dışındaki üniversitelerin, araştırma merkezleri ve firmalar ile anlaşarak oluşturdukları uygulama stüdyoları, öğrencilere proje çalışmalarını inşa etme fırsatı sunarak uygulama aşamasındaki tüm adımları görmelerini ve uygulama deneyimi kazanmalarını sağlamaktadır. Türkiye için imkanlar dahilinde bu yönde bir uygulamaya gidilmesi tavsiye edilmektedir. Uygulamalı proje çalışması yapılamasa bile sürdürülebilirlik ilkelerine bağlı kalınarak tasarlanmış olan projelerin şantiyelerine ziyaretler düzenlenmelidir. Öğrenciler sistemleri sadece kitaplardan veya sanal ortamdan değil gerçek anlamda uygulamalarda görmelidir.

Proje çalışmaları maket veya simülasyon programları ile desteklenmelidir. Böylece projenin uygulaması yapılamasa bile tasarlanan sistemin kurgusu öğrenci tarafindan üç boyutlu olarak şekillendirilmiş olacaktır.

Simülasyon programlarına proje gibi bazı derslerin içeriklerinde yer verilmektedir. Fakat bu daha çok öğrencilerin kendi çabaları dahilinde gerçekleştirilen bir uygulamadır. Öğrencilere enerji 
simülasyon programları ders olarak verilmelidir. Türkiye'deki üniversitelerin bu konuda yeterli düzeyde olmadığı düşünülmektedir. Ayrıca üniversitelerin anlaşmalı lisanslı programlarına, mimarlık alanındaki simülasyon programlarını da dahil etmeleri önerilmektedir.

Laboratuvar şartları da yeterli düzeyde sağlanamamakta olup üniversitelerin genelinde hiç bulunmamaktadır. Bu kapsamda mutlaka yeni bir düzene gidilmesi gerekmekte, deney ve analizlerin yapılabilmesi için mimarlık bölümlerine ait laboratuvar ortamlarının oluşturulması gerekmektedir.

Yurtdışı üniversitelerinin, Türkiye'deki üniversitelerden ayrılan önemli bir yönü araştırma merkezleri ve kurumlarla işbirliği içinde çalışmalarıdır. Türkiye'de yer alan üniversitelerde de Bakanlık veya Meslek örgütlerinin desteği ile mimarlıkta ve binalarda sürdürülebilirliği sağlayabilecek, yarattı̆̆ı zorluklarla başa çıkabilecek uzmanlar yetiştirmek için destek kursları açılmalıdır. Bu kapsamda yetiştirilecek olan uzmanlara sertifika verilmelidir. Böylece alanında yetkin, denetmen, proje yöneticisi, danışman vb. gibi özelliklere sahip olabilecek uzmanların yetiştirilmesi sağlanmalıdır.

Sürdürülebilirlik kapsamında yaz döneminde seminerler, workshoplar, yurtdışı deneyimleri, alana yönelik eksik görülen konularda destek kursları düzenlenerek öğrencilerin daha çok etkileşimde olmaları ve kendilerini geliştirmeleri sağlanmalıdır.

\section{Sonuç}

Mimarların tasarım ve bina teknolojilerinde sürdürülebilirlik paradigmasının gereksinimlerini karşılayabilmeleri, ayrılmaz bir şekilde yeterli mesleki bilgi ve uzmanlıkla bağlantılıdır. Bu alanda yapılan uygulamalar nispeten yeni olduğu ve bu nedenle hala deneyime dayanmadığ için, mimarlık alanından mezun olacak adayların bu alanda bilgi birikimine sahip olacakları bir eğitim sisteminden geçmeleri gerekmektedir. Özetle, sürdürülebilirlik kaçınılmaz olarak gerçekleşmesi gereken bir konudur. Enerji kaynaklarının durumu da göz önünde bulundurulduğunda ilerleyen yıllarda karşılaşılacak olan zorunluluklara karşı mimarlık bölümlerinin bu adımı atması gerekmektedir. Çalışmanın sonucunda, mimarlık bölümü yüksek lisans programı müfredatlarının tekrar gözden geçirilmesi ve sürdürülebilirlik konularının dahil edilmesi için gerekli güncellemelerin yapılması gerekliliği gündeme getirilmek istenmiş olmakla birlikte çözüm önerileri sunulmuştur. Sunulan öneriler referans alınarak, sürdürülebilirliğin mimarlık yüksek lisans programları ile bütünleştirilmesine yönelik bir model geliştirilebilir. 
Gökşen, F., Ayçam, I., Bekler, C., Uluslararası Doğu Anadolu Fen Mühendislik ve Tasarım Dergisi / International Journal of Eastern Anatolia Science Engineering and Design (IJEASED)

(2020) 2(2):401-433

\section{Teșekkür}

Bu çalışmanın özet bildirimi “18-21 Kasım 2020’de Karabük Üniversitesi, Mimarlık Fakültesi tarafından Safranbolu'da Uluslararası Mimarlık Araştırmaları Sempozyumu (ReseArch'20)" kongresinde sözlü sunum olarak sunulmuş olup, kongre üyelerine teşekkür ederiz.

\section{Kaynaklar}

Altomonte, S., (2012). Sustainable Architectural Education: EDUCATE-Environmental Design in University Curricula and Architectural Training in Europe. University of Nottingham, United Kingdom: EDUCATE Press.

Antonara, E., Georgi, J., and Lianos, N. (2013). Sustainable architecture through an environmental educational program. In Paper Presented at the 4th International Conference on Renewable Energy Sources and Energy Efficiency-New Challenges, Nicosia, Cyprus.

Davis, D. (2010). AC 2010-493: Integrating Sustainability Into Studio Design Curriculum. age, 15, 1.

Deviren, A. S. (2019). Sürdürülebilir Kalkınmada Mimarlık Eğitiminin Rolü: Antakya/Hatay’da Yer, Ekolojik Ve Yenileyici Tasarım, Kent Ve Mimarlık Eğitimi Üzerine. Sürdürülebilir Kalkınma Rolüyle Mimarlık, 1. Eskișehir: Eskișehir Teknik Üniversitesi yayınları.

Dupré, K., Alby, E., Flament, B., Jakubik, J., and Kuhn, C. (2008). Buildings' Sustainable Modernization: Towards New Working Relationships. Proceedings of the Ecocity World Summit, San Francisco, USA.

Gamble, J. M., Gentry, R., Augenbroe, G., and Stephen Taul with students from the Georgia Institute of Technologyi. (2015). Architecture and high performance building at Georgia tech: teaching design+ technology in the environmental context. Journal of Green Building, 10(3), 67-86.

GlobalABC, IEA, UNE. (2019). Global status report for buildings and construction: towards a zero emissions, efficient and resilient buildings and construction sector.

Hengrasmee, S. and Chansomsak, S. (2016). A novel approach to architectural education for sustainability: a quest for reformation and transformation. Global Journal of Engineering Education, 18(3).

Karatepe, Y., Nese, S.V., Keçebas, A., and Yumurtaci, M., (2012). The levels of awareness about the renewable energy sources of university students in Turkey. Renewable Energy. 44, 174-179.

Kayıhan, K.S., ve Tönük, S., (2008). Sürdürülebilir Temel Eğitim Binası Tasarımı Bağlamında Arsa Seçimi ve Analizi Konusunun İrdelenmesi, MEGARON/Yıldız Teknik Üniversitesi, Mimarlık Fakültesi EDergisi, 3(2), 137-154.

Kim J-J., (1998). Introduction to sustainable architecture. Ann Arbor (MI): National Pollution Prevention Centre for Higher Education.

Mavromatidis, L. E. (2016). Study of coupled transient radiation-natural convection heat transfer across rectangular cavities in the vicinity of low emissivity thin films for innovative building envelope applications. Energy and Buildings, 120, 114-134.

Mavromatidis, L. (2018). Coupling architectural synthesis to applied thermal engineering, constructal thermodynamics and fractal analysis: An original pedagogic method to incorporate "sustainability" into architectural education during the initial conceptual stages. Sustainable Cities and Society, 39, 689-707.

McDonough, W., and Braungart, M. (2010). Cradle to cradle: Remaking the way we make things. New Yorrk: North point press.

Riguet, J. C., General, S., Cox, L., Mejia, S. M. G., Hyett, P., Koudryavtsev, A., ... and Scheeler, J. (2008). UIA and architectural education reflections and recommendations. XXIIth UIA Geneal Assembly (Berlin, Germany, July 2002), 1-43.

Seif Hattan, A., Feder, J., Naik, A. Murphy, K., Davis, N. Esiet, U., Vithlani, K., and Rigaud, G., (2010). Advancing Education for Sustainability: Teaching the Concepts of Sustainable Building to All Students. Boston: Second Nature, Washington D.C: MA and the US Green Building Council. 
Taleghani, M., Ansari, H. R., and Jennings, P. (2011). Sustainability in architectural education: A comparison of Iran and Australia. Renewable energy, 36(7), 2021-2025.

UNEP SBCI. (2009). Buildings and climate change: Summary for Decision-Makers United Nations Environment Programme, (pp. 62), Paris

UNESCO, UIA, (1996), Mimarlık Eğitim Şartı.

URL-1.https://architecture.ku.edu/master-architecture-0, (Erişim Tarihi: 15.05.2020).

URL-2.https://catalog.ku.edu/architecture/architecture/master-architecture-three-year/, （Erişim Tarihi: 15.05.2020).

URL-3. https://architecture.ku.edu/master-architecture-0, (Erişim Tarihi: 15.05.2020).

URL-4.https://catalog.ku.edu/architecture/architecture/master-architecture-three-year/\#plantext, Tarihi: 15.05 .2020$)$.

URL-5.https://www.ntnu.edu/studies/mssusarc/about, (Erişim Tarihi:08.05.2020).

URL-6. https://www.ntnu.edu/studies/plans\#programmeCode=MSSUSARC\&year=2019, Tarihi:08.05.2020).

URL-7.https://www.jefferson.edu/academics/colleges-schools-institutes/architecture-and-the-builtenvironment.html\#programs, (Erişim Tarihi: 16.05.2020).

URL-8. https://www.jefferson.edu/academics/colleges-schools-institutes/architecture-and-the-builtenvironment/programs/sustainable-design-ms.html, (Erişim Tarihi: 16.05.2020).

URL-9. https://studyarchitecture.com/school/thomas-jefferson-university/, (Erişim Tarihi: 16.05.2020).

URL-10. https://www.behance.net/robertfleming/, (Erişim Tarihi: 16.05.2020).

URL-11. https://www.jefferson.edu/academics/colleges-schools-institutes/architecture-and-the-builtenvironment/programs/sustainable-design-ms/degree-options/graduate-certificates.html,

(Erişim Tarihi: 16.05 .2020$)$.

URL-12. https://www.jefferson.edu/academics/colleges-schools-institutes/architecture-and-the-builtenvironment/programs/sustainable-design-ms/degree-options/full-time-on-campus.html,

(Erişim Tarihi: 16.05.2020).

URL-13. https://kish.ut.ac.ir/en/-/energy-and-architecture, (Erişim Tarihi: 18.05.2020).

URL-14. https://ut.ac.ir/en/page/1166/master-s-degree-in-iranian-studies-kish-international-campus, (Erişim Tarihi: 18.05.2020).

URL-15. http://petek.fbe.itu.edu.tr/programmes.aspx?i=251, (Erişim Tarihi: 15.05.2020).

URL-16. http://www.fbe.itu.edu.tr/mevcut-ogrenciler/yuksek-lisans/yl-ders-asamasi-sureci, (Erişim Tarihi: 15.05.2020).

URL-17. http://www.mim.yildiz.edu.tr/images/files/yapi\%20fizigi(1).jpg, (Erişim Tarihi: 15.05.2020).

URL-18. http://www.bologna.yildiz.edu.tr/index.php?r=program/view\&id=247\&aid=38, (Erişim Tarihi: 15.05.2020).

URL-19. https://architecture.iyte.edu.tr/yuksek-lisans/, (Erişim Tarihi: 16.05.2020).

URL-20. https://iyte.edu.tr/wp-content/uploads/2019/03/15.pdf, (Erişim Tarihi: 16.05.2020).

URL-21. http://gbp.gazi.edu.tr//htmlProgramHakkinda.php?dr=0\&lang=0\&baslik=1\&FK=83\&BK=11\&ders _kodu $=\&$ sirali $=0 \&$ fakulte $=$ FEN+B $\%$ DDL $\%$ DDMLER $\%$ DD+ENST $\%$ DDT $\%$ DCS\%DC\&fakulte_en $=$ GRADUATE+SCHOOL+OF+NATURAL+AND+APPLIED+SCIENCES\&bolum=M\%DDMARLIK \&bolum_en=ARCHITECTURE\&ac=11, (Erişim Tarihi: 16.05 .2020$)$.

URL-22. http://abl.gtu.edu.tr/ects/?duzey=ucuncu\&bolum=326\&tip=yukseklisans, Son Erişim Tarihi: 15.05.2020

URL-23. http://www.gtu.edu.tr/Files/UserFiles/106/duyuru/GTU_Lisansustu_210417.pdf, （Erişim Tarihi: 15.05.2020).

URL-24. http://itulabs.itu.edu.tr/LaboratuvarListesi.aspx, (Erişim Tarihi: 18.05.2020).

URL-25. http://studio804.blogspot.com/?view=classic, (Erişim Tarihi: 22.05.2020).

URL-26. http://www.gtu.edu.tr/icerik/2541/4774/display.aspx?languageId=1, (Erişim Tarihi: 23.05.2020).

Uzunoglu, S. S., and Uzunoglu, K. (2011). The application of formal perception of gestalt in architectural education. Procedia-Social and Behavioral Sciences, 28, 993-1003.

Imperatives, S. (1987). Report of the World Commission on Environment and Development: Our common future. Accessed Feb, 10.

Yeang, K. (2006). Ecodesign: A manual for ecological design. New York: Wiley Academy. 